\title{
Neuroprotective Effects of Necrostatin-1 Against Oxidative Stress-Induced Cell Damage: an Involvement of Cathepsin D Inhibition
}

\author{
Danuta Jantas $^{1}$ (D) Jakub Chwastek ${ }^{1,2}$ (D) Beata Grygier ${ }^{1,3}$ (D) $\cdot$ Władysław Lasoń ${ }^{1}$ (D)
}

Received: 31 July 2019 / Revised: 7 January 2020 / Accepted: 10 January 2020 /Published online: 21 January 2020

(C) The Author(s) 2020

\begin{abstract}
Necroptosis, a recently discovered form of non-apoptotic programmed cell death, can be implicated in many pathological conditions including neuronal cell death. Moreover, an inhibition of this process by necrostatin-1 (Nec-1) has been shown to be neuroprotective in in vitro and in vivo models of cerebral ischemia. However, the involvement of this type of cell death in oxidative stress-induced neuronal cell damage is less recognized. Therefore, we tested the effects of Nec-1, an inhibitor of necroptosis, in the model of hydrogen peroxide $\left(\mathrm{H}_{2} \mathrm{O}_{2}\right)$-induced cell damage in human neuroblastoma SH-SY5Y and murine hippocampal HT-22 cell lines. The data showed that Nec-1 (10-40 $\mu \mathrm{M})$ attenuated the cell death induced by $\mathrm{H}_{2} \mathrm{O}_{2}$ in undifferentiated (UN-) and neuronal differentiated (RA-) SH-SY5Y cells with a higher efficacy in the former cell type. Moreover, Nec-1 partially reduced cell damage induced by 6-hydroxydopamine in UN- and RA-SH-SY5Y cells. The protective effect of Nec-1 was of similar magnitude as the effect of a caspase-3 inhibitor in both cell phenotypes and this effect were not potentiated after combined treatment. Furthermore, the non-specific apoptosis and necroptosis inhibitor curcumin augmented the beneficial effect of Nec-1 against $\mathrm{H}_{2} \mathrm{O}_{2}$-evoked cell damage albeit only in RA-SH-SY5Y cells. Next, it was found that the mechanisms of neuroprotective effect of $\mathrm{Nec}^{-1}$ against $\mathrm{H}_{2} \mathrm{O}_{2}$ induced cell damage in SH-SY5Y cells involved the inhibition of lysosomal protease, cathepsin D, but not caspase-3 or calpain activities. In HT-22 cells, Nec-1 was protective in two models of oxidative stress $\left(\mathrm{H}_{2} \mathrm{O}_{2}\right.$ and glutamate) and that effect was blocked by a caspase inhibitor. Our data showed neuroprotective effects of the necroptosis inhibitor, Nec-1, against oxidative stress-induced cell damage and pointed to involvement of cathepsin D inhibition in the mechanism of its action. Moreover, a cell type-specific interplay between necroptosis and apoptosis has been demonstrated.
\end{abstract}

Keywords Hydrogen peroxide $\cdot$ SH-SY5Y cells $\cdot$ HT-22 cells $\cdot$ Caspase- 3 - Glutamate $\cdot$ Pepstatin A

\section{Introduction}

Necroptosis, a form of non-apoptotic programmed cell death, was shown to be activated in various models of acute (stroke,

Danuta Jantas

jantas@if-pan.krakow.pl

1 Department of Experimental Neuroendocrinology, Maj Institute of Pharmacology Polish Academy of Sciences, Smętna Street 12, 31-343 Kraków, Poland

2 Present address: Department of Neurochemistry, Maj Institute of Pharmacology Polish Academy of Sciences, Smętna Street 12, 31-343 Kraków, Poland

3 Present address: Department of Immunology, Faculty of Biochemistry, Biophysics and Biotechnology, Jagiellonian University, Gronostajowa 7 Street, 30-387 Kraków, Poland traumatic brain, or spinal cord injuries) and chronic (Alzheimer's disease (AD), Parkinson's disease (PD), and amyotrophic lateral sclerosis (ALS)) neurodegenerative conditions (Caccamo et al. 2017; Re et al. 2014; Vieira et al. 2014; Yin et al. 2015). This cell death pathway can be distinguished from apoptosis based on morphological and biochemical criteria. The cell dying by necroptosis is characterized by the loss of plasma membrane integrity, swelling of cellular organelles, and lack of typical nuclear fragmentation. Moreover, it can be activated by members of the tumor necrosis factor (TNF) family (TNFR1, TNFR2, TRAILR1, TRAILR2), Fas ligand, toll-like receptors (TLRs), lipopolysaccharides (LPS), pathogens (bacteria and viruses), genotoxic stress, glutamate (Glu), or calcium overload, and is thought to be a caspaseindependent process. A crucial step in initiation and execution of necroptosis involves the activation of receptor-interacting serine/threonine-protein (RIP) kinases (RIP1 and RIP3) and 
formation of the necrosome complex (Degterev et al. 2014; Zhao et al. 2015).

In recent years, various inhibitors of necroptosis have been experimentally tested in relation to various human pathologies and used for mechanistic investigation of this process (Degterev et al. 2005, 2008, 2013; Delehouzé et al. 2017; Do et al. 2017; Li et al., 2018; Xie et al. 2013). Among them, necrostatin-1 (Nec-1; methyl-thiohydantoin-tryptophan) was the first to be identified and since then used the most frequently (Degterev et al. 2005, 2008). The neuroprotective potential of Nec-1 and its analogs in cellular and animal models of ischemia is rather well supported (Chavez-Valdez et al. 2012, 2016; Degterev et al. 2005; Li et al. 2018; Ni et al. 2018; Northington et al. 2011; Xu et al. 2010a; Yang et al. 2017a; Yin et al. 2015; Zhan et al. 2019; Zhang et al. 2016). Moreover, in an in vitro setting, Nec-1 attenuated the neuronal cell damage induced by various harmful agents, e.g., oaubain, glutamate (Glu), N-methyl-D-aspartate (NMDA), 6hydroxydopamine (6-OHDA), rotenone, 1-methyl-4phenylpyridinium ion (MPP+), methamphetamine, aluminum (Al), 24(S)-hydroxycholesterol, cholesterol, staurosporine, and doxorubicin (Funakoshi et al. 2016; Ito et al. 2017; Jantas et al. 2014a; Li et al. 2011; Wang et al. 2014; Wu et al. 2015; Xiong et al. 2016; Xu et al. 2007; Yamanaka et al. 2011; Zhang et al. 2013). It should be noted that the protective effect of Nec-1 in the above studies was only partial, suggesting the participation of other than necroptosis cell death programs which can vary depending on the type of neuronal injury as has already been shown by in vivo (ischemia, traumatic brain injury, spinal cord injury, retina injury) and in vitro studies (e.g., Al-, iron-, 6-OHDA-, or $\beta$-amyloidinduced neurotoxicity) (Askalan et al. 2015; Chinskey et al. 2014; Dai et al. 2013; Dong et al. 2012; Liu et al. 2014; Rosenbaum et al. 2010; Qinli et al. 2013; Wu et al. 2015; $\mathrm{Xu}$ et al. 2010a; Zhang et al. 2008). Consequently, a potential synergistic effect has been proposed after combined treatment with various cell death-specific inhibitors (Koshinuma et al. 2014; Xu et al. 2010a).

With the aim to extend a neuroprotective portfolio of Nec1 , in the present study, we tested the hypothesis that this compound protects human neuroblastoma SH-SY5Y cells against the hydrogen peroxide $\left(\mathrm{H}_{2} \mathrm{O}_{2}\right)$ - and 6-hydroxydopamine (6OHDA)-induced cell damage. The used experimental models are widely accepted as cellular models of PD, where elevated oxidative stress is a significant contributor to neuropathology of this disease (Agholme et al. 2010; Castelli et al. 2019; Cenini et al. 2019; Cheung et al. 2009; Miloso et al. 2004). Based on our previous experiences, where neuronal differentiation of SH-SY5Y cells could mask or limit a protective effect of the tested agents (Jantas et al. 2014b, 2015b), we hypothesized that Nec-1 will afford a greater protection to undifferentiated (UN-SH-SY5Y) cells in comparison with retinoic acid (RA)-differentiated (RA-SH-SY5Y) ones.
Although necrosis and/or apoptosis have been shown to participate in the $\mathrm{H}_{2} \mathrm{O}_{2}$-induced cell damage in SH-SY5Y cells (Chwastek et al. 2017; Jantas et al. 2015a), the involvement of necroptosis has not been studied in detail, yet. In order to test a potential interplay between apoptosis and necroptosis in our models, we co-treated cells with the caspase- 3 inhibitor, AcDEVD-CHO, and Nec-1. Since previous studies showed neuroprotective effects of curcumin in various types of neuronal cell damage (Mhillaj et al. 2019; Szczepanowicz et al. 2016) and the involvement of both apoptosis and necroptosis inhibition has been suggested to be associated with the curcuminmediated protection (Dai et al. 2013; Wang et al. 2017; Xu et al. 2019), we studied a potential synergism in neuroprotective effects of Nec-1 and curcumin (Curc) in UN- and RA-SHSY5Y cells. Next, we searched for putative mechanisms involved in neuroprotection mediated by Nec-1 by measuring the apoptotic markers (caspase-3 activity, AIF translocation), calpain activity (145 $\mathrm{kDa}$ cleavage product of spectrin $\alpha$ II) and lysosomal permeability (cathepsin D activity). For confirmation of the results in another type of neuronal cells, we tested the effect of Nec-1 and its possible synergism with a caspase inhibitor (Z-VAD-fmk) in the mouse hippocampal HT-22 cells exposed to $\mathrm{H}_{2} \mathrm{O}_{2}$ or glutamate (Glu).

\section{Materials and Methods}

\section{Drugs and Reagents}

Dulbecco's Modified Eagle's Medium (DMEM), FluoroBrite ${ }^{\mathrm{TM}}$ DMEM, and fetal bovine serum (FBS) were from Gibco (Invitrogen, Paisley, UK). The Cytotoxicity Detection Kit and BM Chemiluminescence Western Blotting Kit were from Roche Diagnostic (Mannheim, Germany). Caspase-3 (Ac-DEVD-AMC) and cathepsin D (MOCA-GlyLys-Pro-Ile-Leu-Phe-Phe-Arg-Leu-Lys(Dnp)-D-Arg-NH2) fluorogenic substrates were obtained from Enzo Life Sciences (NY, USA). Caspase-1 substrate (Ac-YVAD-AMC) and inhibitor (Ac-YVAD-CHO) were obtained from Promega (Madison, WI, USA). Primary antibodies, anti-spectrin $\alpha$ II (sc-48382), anti-AIF (sc-5586), anti-cathepsin D (sc-6486), anti-GAPDH (sc-25778), and MW standards (sc-2035), and secondary antibodies (sc-2004, sc-2005, sc-2020, and sc2030) were purchased from Santa Cruz Biotechnology Inc. (CA, USA). All other reagents were from Sigma (SigmaAldrich Chemie GmbH, Germany).

\section{SH-SY5Y Cell Culture}

The human SH-SY5Y neuroblastoma cells (ATCC, passages 5-20) were grown in DMEM supplemented with $10 \%(\mathrm{v} / \mathrm{v})$ heat-inactivated FBS and 100 units/ml of penicillin and $100 \mu \mathrm{g} / \mathrm{ml}$ of streptomycin as described previously (Jantas 
et al. 2015b). Cells were maintained at $37^{\circ} \mathrm{C}$ in a saturated humidity atmosphere containing $95 \%$ air and $5 \% \mathrm{CO}_{2}$. After reaching an $80 \%$ confluence, cells were counted with a LUNA ${ }^{\mathrm{TM}}$ Automatic Cell Counter (Logos Biosystems, Inc., Korea) and seeded at a density of $5 \times 10^{4}, 2.5 \times 10^{5}$, and $1 \times 10^{6}$ cells per well into 96-, 24-, and 6-well plates, respectively. To obtain differentiated cells (RA-SHSY5Y), the cells were plated at a half of the densities mentioned above and cultured in medium supplemented with retinoic acid (RA, $10 \mu \mathrm{M}$ ) for 6 days, during which the culture medium was changed every 2 days. One day before treatment, the culture medium for undifferentiated (UNSH-SY 5Y) and RA-SH-SY5Y cells was replaced with DMEM containing antibiotics and $1 \%(\mathrm{v} / \mathrm{v}) \mathrm{FBS}$.

\section{HT-22 Cell Culture}

The immortalized mouse hippocampal cell line HT-22 (passages 302-308; kind gift from Prof. Carsten Culmsee, Institute of Pharmacology and Clinical Pharmacy, University of Marburg, Germany) was grown in DMEM supplemented with $10 \%$ (v/v) FBS and 1\% (v/v) penicillin/streptomycin as reported previously (Chwastek et al. 2017; Dolga et al. 2013). After trypsinization, the cells were counted (LUNA TM Automatic Cell Counter, Logos Biosystems, Inc., Korea) and seeded into 96-well plates at a density of $2 \times 10^{4}$ and $8 \times 10^{3}$ cells/well for $\mathrm{H}_{2} \mathrm{O}_{2}$ - and Glu-induced cell damage, respectively. Cells were maintained at $37{ }^{\circ} \mathrm{C}$ in a saturated humidity atmosphere containing $95 \%(\mathrm{v} / \mathrm{v})$ air and $5 \%(\mathrm{v} / \mathrm{v})$ $\mathrm{CO}_{2}$. One day before treatment, the culture medium for the model of $\mathrm{H}_{2} \mathrm{O}_{2}$-evoked cell damage was replaced with DMEM containing 1\% (v/v) FBS and antibiotics. For Glumediated oxytosis, the medium contained $10 \%$ (v/v) FBS (Dolga et al. 2013).

\section{Cell Treatment}

The cells were pre-treated with various concentrations of Nec$1(1-40 \mu \mathrm{M})$ for $30 \mathrm{~min}$ followed by $24 \mathrm{~h}$ exposure to cell damaging factors $\left(\mathrm{H}_{2} \mathrm{O}_{2}, 6-\mathrm{OHDA}\right.$, Glu). The chosen concentrations of Nec-1 were based on literature search and included not active $(<1 \mu \mathrm{M})$ and RIP1-specific $(>3 \mu \mathrm{M})$ concentrations (Degterev et al. 2008; Ito et al. 2017; Yamanaka et al. 2011; Yang et al. 2017b, 2019). For comparison of the Nec-1 effects with other protectants, the antioxidant, Nacetylcysteine (NAC, $1 \mathrm{mM}$ ), and curcumin (Curc, $5 \mu \mathrm{M}$ ) were used. The effective concentrations of $\mathrm{H}_{2} \mathrm{O}_{2}(0.25$ and $0.5 \mathrm{mM}$ for UN- and RA-SH-SY5Y cells, respectively; $1 \mathrm{mM}$ for HT-22 cells) were established in our previous studies, in which this agent reduced cell viability by approximately 50\% (Chwastek et al. 2017; Jantas et al. 2015a). The chosen concentrations of 6-OHDA ( 0.1 and $0.2 \mathrm{mM}$ for UN- and RASH-SY5Y cells, respectively) or Glu (3 mM) were based on the published literature (Cheung et al. 2009; Dolga et al. 2013; Tieu et al. 1999). For mechanistic studies, inhibitors of calpain (MDL28170; $10 \mu \mathrm{M})$ ), cathepsin D (pepstatin A; PsA; $0.2 \mu \mathrm{M}$ ), caspase-3 (Ac-DEVD-CHO; $20 \mu \mathrm{M}$ ), caspase-1 (Ac-YVAD-CHO; $20 \mu \mathrm{M})$, and pan-caspase inhibitor (ZVAD-fmk; $20 \mu \mathrm{M})$ were used.

Nec-1 (100 mM), MDL28170 (10 mM), PsA (10 mM), Ac-DEVD-CHO (10 mM), Ac-YVAD-CHO (10 mM), ZVAD-fmk (10 mM), and Curc (10 mM) stock solutions were prepared in DMSO. The final solutions of the tested chemicals were prepared in distilled water except for those of Curc which were prepared in a mixture of $\mathrm{dH}_{2} \mathrm{O}$ and DMSO (1:1). The $\mathrm{H}_{2} \mathrm{O}_{2}$ stock solutions (25 and $50 \mathrm{mM}$ ) were prepared freshly from stabilized $30 \%$ (w/w) hydrogen peroxide diluted in distilled water. The 6-OHDA stock solutions (10 and $20 \mathrm{mM}$ ) were prepared in distilled water immediately before use. All agents were added to the culture medium at the indicated concentrations under light limited conditions. Each experimental set of the control cultures was supplemented with the appropriate vehicles, and the solvent was present in cultures at a final concentration of $0.1 \%(\mathrm{v} / \mathrm{v})$.

\section{Cell Viability Assay}

Cell viability of UN- and RA-SH-SY5Y or HT-22 cells growing in 96-well plate format after $24 \mathrm{~h}$ of particular treatments was quantified using a tetrazolium salt colorimetric assay with 3-[4,5-dimethylthiazol-2-yl]-2,5-diphenyltetrazolium bromide (MTT) as described previously (Jantas et al. 2015a). The data were normalized to the vehicle-treated cells $(100 \%)$ and expressed as a percent of the control \pm SEM established from 3 to 11 independent experiments with 5 replicates.

\section{LDH Release Assay}

The level of lactate dehydrogenase (LDH) released into culture media from UN-, RA-SH-SY5Y, or HT-22 cells after $24 \mathrm{~h}$ of treatment with $\mathrm{Nec}-1$ and $\mathrm{H}_{2} \mathrm{O}_{2}$ was measured with Cytotoxicity Detection Kit (Roche) as described previously (Jantas et al. 2015a). The data were normalized to the vehicle-treated cells and expressed as a percent of the control \pm SEM from 3 to 11 independent experiments with 5 replicates.

\section{PI Staining and Flow Cytometry}

To confirm the results obtained by biochemical cell viability/ toxicity assays, the SH-SY5Y and HT-22 cells were stained with propidium iodide (PI) according to the method described previously (Jantas et al. 2015a). A total of $1 \times 10^{4}$ cells were analyzed using a BD FACS Canto II System and BD FACSDiva $^{\mathrm{TM}}$ v5.0.1 Software (BD Biosciences) in the fluorescence channel for PerCP-Cy5-5-A (red fluorescence). The 
cells exhibiting loss of cell membrane integrity (PI positive) represent necrotic and late apoptotic cells. Data are presented as a percentage of PI-positive cells ( \pm SEM) established from 3 to 5 independent experiments with 2 replicates.

\section{CalceinAM/Hoechst 33342 Staining and Image Analysis}

In order to assess the morphology and viability of the UN- and RA-SH-SY5Y cells after 9 and $18 \mathrm{~h}$ of treatment with Nec-1 $(20 \mu \mathrm{M})$ and $\mathrm{H}_{2} \mathrm{O}_{2}(0.25$ and $0.5 \mathrm{mM}$ for UN- and RA-SHSY5Y cells, respectively), we performed live cell imaging by employing a double staining of cells with cell-permeable CalceinAM (marker of viable cells) and Hoechst 33342 (nuclei marker) dyes, as described previously (Fraczek-Szczypta et al. 2018). The cells after labeling were placed in FluoroBrite ${ }^{\mathrm{TM}}$ DMEM and were evaluated by using an inverted fluorescence microscope (AxioObserver, Carl Zeiss) with an excitation wavelength of $480 \mathrm{~nm}$ (CalceinAM) and $355 \mathrm{~nm}$ (Hoechst 33342) equipped with a black-white camera (Axio-CamMRm, Carl Zeiss). Five microphotographs for each panel (480 or $355 \mathrm{~nm}$ ) were taken for each tested group in duplicates for each endpoint ( 9 or $18 \mathrm{~h}$ ) from 2 independent experiments. The numbers of pyknotic (condensed and/or fragmented) and healthy nuclei were counted semi-manually from a 355-nm panel using AxioVison software for each taken microphotograph, averaged from 5 photos per well and the data are presented as the mean \pm SEM. To evaluate the impact of the tested agents on neurite morphology, the neurite length was measured from a 480-nm panel using Simple Neurite Tracer (an ImageJ addon software) as described previously (Fraczek-Szczypta et al. 2018). The lengths of ten random neurites per image, 3 images per well, and 2 wells per experimental group were measured. The data are presented as the mean neurite length \pm SEM (in $\mu \mathrm{m})$ from 2 independent experiments.

\section{Caspase- 3 and Caspase-1 Activity Assays}

The caspase-3 activity in UN- or RA-SH-SY5Y cells growing in 6-well format and treated for 9 or $18 \mathrm{~h}$ with $\mathrm{H}_{2} \mathrm{O}_{2}$ and Nec-1 was measured using fluorogenic substrate Ac-DEVD-AMC $(50 \mu \mathrm{M})$ as described in detail previously (Jantas et al. 2015a). Caspase-3 inhibitor, Ac-DEVD-CHO $(20 \mu \mathrm{M})$, was used to verify the assay specificity. Moreover, we measured caspase- 3 and caspase- 1 activities in RA-SH-SY5Y cells after 9 and $18 \mathrm{~h}$ of treatment with Nec-1 $(20 \mu \mathrm{M})$, Curc $(5 \mu \mathrm{M})$, and $\mathrm{H}_{2} \mathrm{O}_{2}(0.5 \mathrm{mM})$. Caspase- 1 activity was measured according to a similar procedure as caspase-3 but with a different substrate (Ac-YVAD-AMC, $50 \mu \mathrm{M}$ ) and inhibitor (Ac-YVAD$\mathrm{CHO}, 20 \mu \mathrm{M}$ ) as described previously (Jantas et al. 2018a). The data (expressed as mean relative fluorescence units, RFU) first were normalized to protein level (measured by BCA method) and next calculated as a percent of vehicle-treated cells and presented as the mean \pm SEM from 2 to 3 separate experiments with 2 repetitions each.

\section{Cathepsin D Activity Assay}

Cathepsin D activity in UN- and RA-SH-SY5Y cells treated for $18 \mathrm{~h}$ with $\mathrm{H}_{2} \mathrm{O}_{2}$ and Nec-1 was measured using a fluorometric method employing the fluorogenic substrate AMCGly-Lys-Pro-Ile-Leu- Phe-Phe-Arg-Leu-Lys(Dnp)-D-ArgNH2 as described previously (Chwastek et al. 2017). PsA $(0.2 \mu \mathrm{M})$ was used as a positive control for the assay. Cathepsin D activity expressed in RFU first was calculated per milligram of protein and next normalized to the vehicletreated cells; it is shown as the mean \pm SEM from 3 to 4 independent experiments with 2 replicates.

\section{Western Blot}

For Western blot analysis of spectrin $\alpha$ II cleavage products in whole cell lysates, UN- or RA-SH-SY5Y cells were cultured in 6-well plates and pre-treated for $30 \mathrm{~min}$ with $\mathrm{Nec}-1$ $(20 \mu \mathrm{M})$ or calpain inhibitor MDL28170 $(10 \mu \mathrm{M})$ followed by $14 \mathrm{~h}$ exposure to $\mathrm{H}_{2} \mathrm{O}_{2}(0.25$ and $0.5 \mathrm{mM}$ for $\mathrm{UN}$ - and RASH-SY5Y cells). For cathepsin D protein measurement (43 and $33 \mathrm{kDa}$ ) in whole cell lysates, UN- and RA-SH-SY5Y cells were pre-treated with Nec-1 $(20 \mu \mathrm{M})$ for 30 min followed by $18 \mathrm{~h}$ exposure to $\mathrm{H}_{2} \mathrm{O}_{2}$. For apoptosis inducing factor (AIF) measurement in cytosolic fraction, UN-SH-SY5Y cells were pre-treated with Nec-1 $(1$ and $20 \mu \mathrm{M})$ for $30 \mathrm{~min}$ followed by $14 \mathrm{~h}$ exposure to $\mathrm{H}_{2} \mathrm{O}_{2}$. The whole cell lysates and cytosolic fractions (for measurement of AIF expression) were prepared as previously described (Jantas et al. 2015a). Equal amounts of protein were separated on $7 \%(\mathrm{w} / \mathrm{v})$ (spectrin $\alpha$ II) or $10 \%(\mathrm{w} / \mathrm{v})(\mathrm{AIF}$, cathepsin D) SDS polyacrylamide gels and transferred onto PVDF membranes. After blocking with $5 \%(\mathrm{w} / \mathrm{v})$ nonfat milk in TBST, the membranes were incubated overnight with primary antibodies diluted at 1:500 (AIF, cathepsin D) and 1:1000 (spectrin $\alpha$ II, GAPDH) in $1 \%(w / v)$ nonfat milk. The amount of GAPDH was determined on the same membrane on which the protein of interest was measured, by stripping and reprobing the membrane as described previously (Jantas et al. 2015a). Data from 2 to 3 independent experiments were normalized to the protein loading control $(\mathrm{GAPDH})$ and are expressed as fold of control $( \pm \mathrm{SEM})$.

\section{Statistical Analysis}

Data were analyzed using the Statistica software (StatSoft Inc., Tulsa, OK, USA). The analysis of variance (one-way ANOVA) and post hoc Tukey's test for multiple comparisons were used to show statistical significance with assumed 
$P<0.05$. For comparison of Nec-1 protective efficiency between UN- and RA-SH-SY5Y cells, a mean area under the curve (AUC) was calculated and statistically analyzed with (GraphPad Prism 7.04) with assumed $P<0.05$. The unpaired $t$ test was also used for comparison of basal activities of caspase-3 or cathepsin D in UN- and RA-SH-SY5Y cells.

\section{Results}

\section{Neuroprotective Effects of Nec-1 Against $\mathrm{H}_{2} \mathrm{O}_{2}-$ and 6-OHDA-Induced Cell Damage in UN- and RA-SH-SY5Y Cells: the Impact of Cell Differentiation State}

Twenty-four hours of treatment with Nec-1 at up to $40 \mu \mathrm{M}$ was safe for UN- or RA-SH-SY5Y cells as confirmed by cell viability assay (Fig. 1a, d). Nec-1 (10-40 $\mathrm{MM}$ ) attenuated the cell damage induced by $\mathrm{H}_{2} \mathrm{O}_{2}$ in UN- and RA-SH-SHY5Y cells (Fig. 1a, d) with a significantly higher protection (measured as a mean area under the curve (AUC)) mediated in the former cell phenotype $(\mathrm{AUC}=95.26 \pm 5.74$ and $\mathrm{AUC}=$ $44.82 \pm 4.34$ for UN- and RA-SH-SY5Y, respectively; $t$ test, $P=0.0009)$. It should be noticed that the neuroprotection mediated by the antioxidant, $\mathrm{N}$-acetylcysteine (NAC, $1 \mathrm{mM}$ ), was comparable with the effect of Nec-1 at its higher concentrations $(20$ and $40 \mu \mathrm{M})$ (Fig. 1). The neuroprotective action of Nec-1 and NAC against $\mathrm{H}_{2} \mathrm{O}_{2}$ was confirmed by the LDH release assay (Fig. 1b, e) and by PI staining in both cell phenotypes (Fig. 1c, f). Moreover, the beneficial effect of Nec-1 on cell viability was also morphologically confirmed by differential interference contrast (DIC) images (Fig. 2) and by CalceinAM staining (Fig. 3a). Additionally, we showed a significant increase in the number of pyknotic nuclei after treatment of UN-SH-SY5Y cells (after $9 \mathrm{~h}$ ) and RA-SH-SY5Y cells (after 9 and $18 \mathrm{~h}$ ) with $\mathrm{H}_{2} \mathrm{O}_{2}$ which was not changed by Nec-1 $(20 \mu \mathrm{M})$ pre-treatment at any of the tested time points (Fig. 3b). However, we observed that Nec-1 partially protected the cells against $\mathrm{H}_{2} \mathrm{O}_{2}$-induced reduction in the number of healthy nuclei which was observed after $18 \mathrm{~h}$ but not after $9 \mathrm{~h}$ of treatment in both cell phenotypes (Fig. $3 \mathrm{c})$. Next, we measured the impact of Nec-1 pre-treatment on $\mathrm{H}_{2} \mathrm{O}_{2}$-evoked neurite shortening after 9 and $18 \mathrm{~h}$ of treatment. In UN-SH-SY5Y cells, we found a significant reduction in this parameter after $18 \mathrm{~h}$ of treatment with $\mathrm{H}_{2} \mathrm{O}_{2}$ which was completely blocked by Nec-1 pre-treatment (Fig. 3d, left panel). In the case of RA-SH-SY5Y cells, the $\mathrm{H}_{2} \mathrm{O}_{2}$ evoked reduction in neurite length after 9 and $18 \mathrm{~h}$ of treatment which was significantly reduced by Nec-1 (Fig. 3d, right panel). a

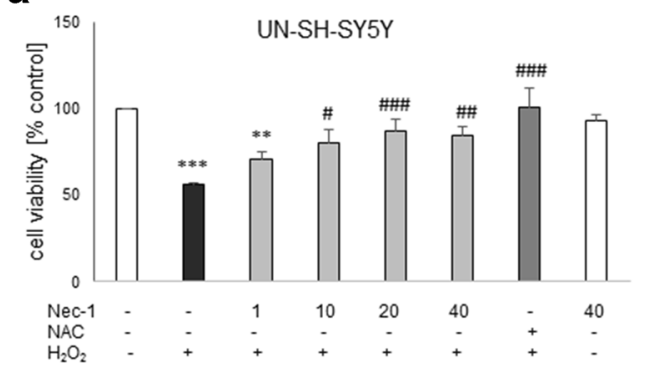

d

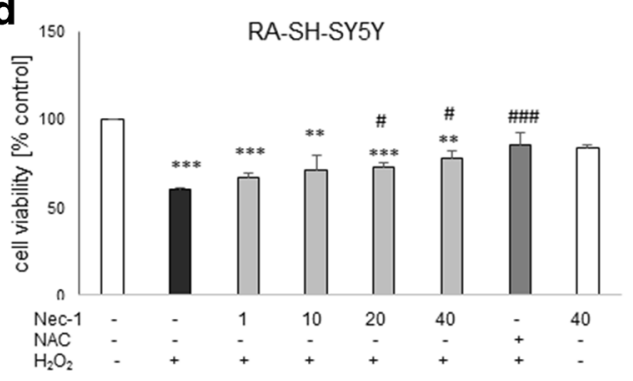

b

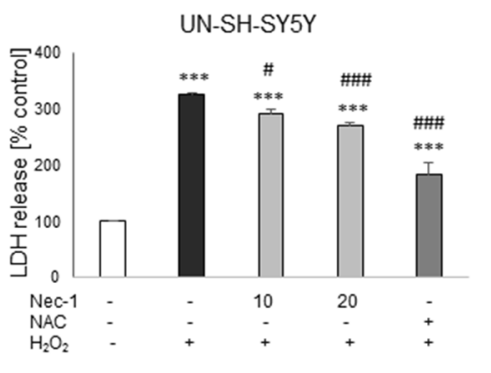

e

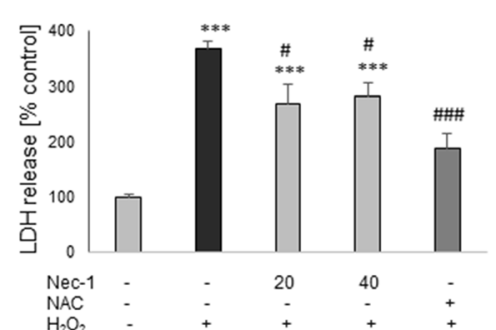

C
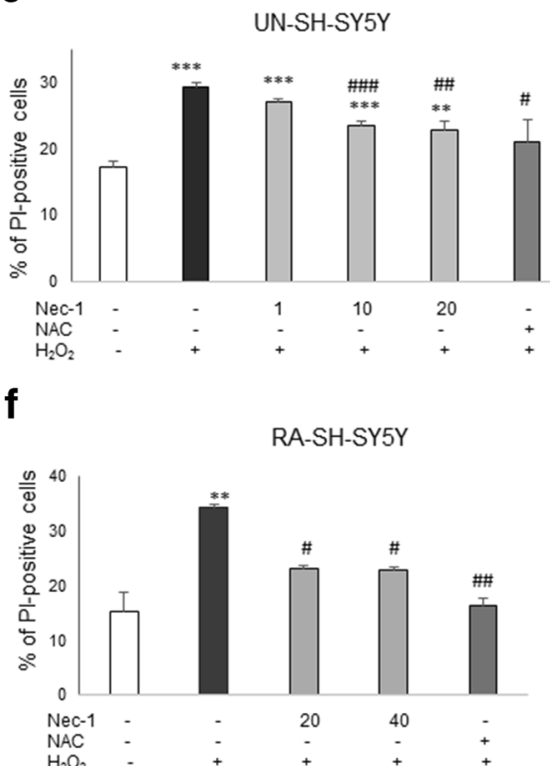

Fig. 1 The effect of necrostatin- 1 on $\mathrm{H}_{2} \mathrm{O}_{2}$-induced cell damage in UNand RA-SH-SY5Y cells. UN- and RA-SH-SY5Y cells (a-c and $\mathbf{d}-\mathbf{f}$, respectively) were pre-treated for $30 \mathrm{~min}$ with necrostatin-1 (Nec-1; 1$40 \mu \mathrm{M})$ followed by $24 \mathrm{~h}$ of treatment with $\mathrm{H}_{2} \mathrm{O}_{2}(0.25$ and $0.5 \mathrm{mM}$ for $\mathrm{UN}$ - and RA-SH-SY5Y, respectively). As a positive control for the assays, we used antioxidant $\mathrm{N}$-acetylcysteine (NAC, $1 \mathrm{mM}$ ) which was given concomitantly with the cell damaging factor. a, d Results of cell viability assessment in UN-(a) and RA-(d) SH-SY5Y cells measured by the MTT reduction assay. Data were normalized to vehicle-treated cells (control) and are presented as the mean \pm SEM from 3 to 11 separate experiments with 5 repetitions each. (b, e) Results of cell toxicity assessment in UN-(b) and RA-(e) SH-SY5Y cells measured by the LDH release assay. Data were normalized to vehicle-treated cells (control) and are presented as the mean \pm SEM from 4 to 11 separate experiments with 5 repetitions each. c, f Flow cytometry results of propidium iodide (PI)stained UN- (c) and RA (f) SH-SY5Y cells after $24 \mathrm{~h}$ of cell treatment. Data are presented as the mean \pm SEM of PI-positive cells from 3 to 5 independent experiments with 2 replicates. $* * P<0.01$ and $* * * P<0.001$ vs. vehicle-treated cells; ${ }^{\#} P<0.05$, ${ }^{\# \#} P<0.01$, and ${ }^{\# \# \#} P<0.001$ vs. $\mathrm{H}_{2} \mathrm{O}_{2}$-treated cells 
Fig. 2 Representative DIC (differential interference contrast) images of UN-SH-SY5Y cells treated for $24 \mathrm{~h}$ with necrostatin-1 (Nec-1, $20 \mu \mathrm{M})$ and hydrogen peroxide $\left(\mathrm{H}_{2} \mathrm{O}_{2}, 0.25 \mathrm{mM}\right)$
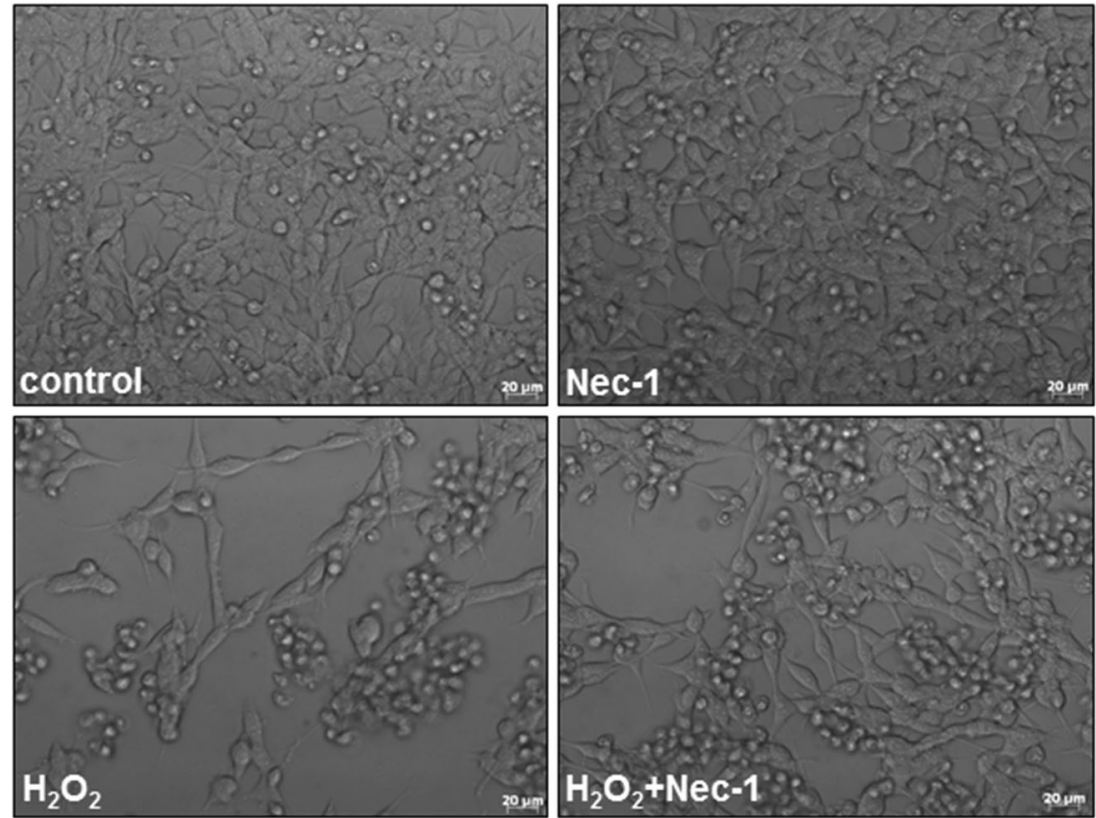

a

\section{옹}

UN-SH-SY5Y
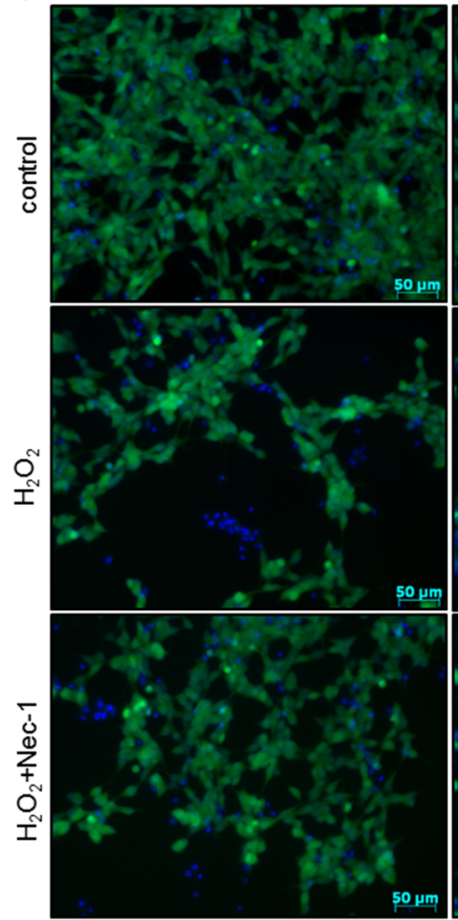

Fig. 3 a Representative microphotographs of UN- and RA-SH-SY5Y cells double-stained with CalceinAM/Hoechst 33342 after $18 \mathrm{~h}$ of treatment with necrostatin-1 (Nec-1; $20 \mu \mathrm{M})$ and hydrogen peroxide $\left(\mathrm{H}_{2} \mathrm{O}_{2}\right.$; 0.25 and $0.5 \mathrm{mM}$ for UN- and RA-SH-SY5Y cells, respectively). b, c An estimation of number of pyknotic (b) and healthy nuclei (c) from Hoechst 33342 staining. Nuclei showing bright blue florescence (condensed or fragmented) staining were semi-manually counted and presented as the mean percentage of pyknotic nuclei/all nuclei \pm SEM or percentage of healthy nuclei (normalized to control group) from two independent b
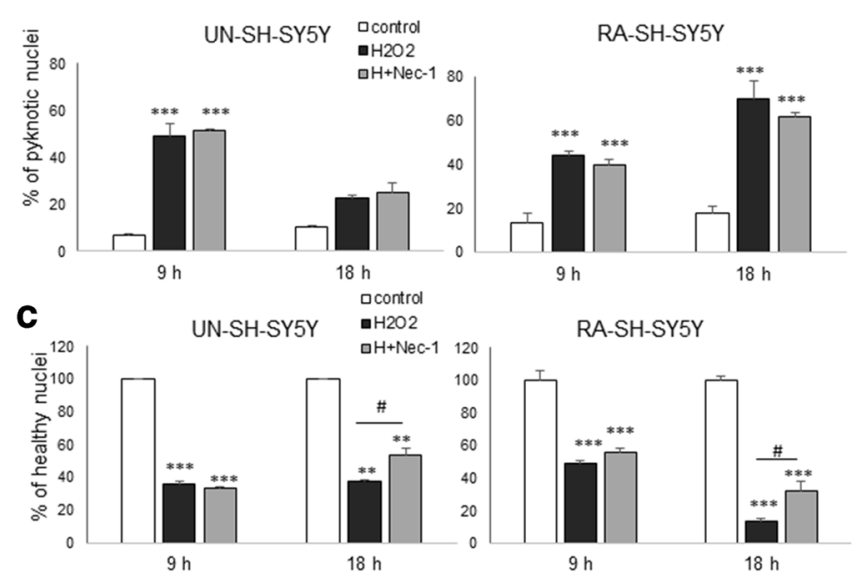

d

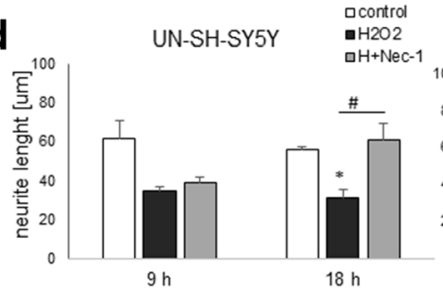

experiments with two replicates. d Quantification of neurite length (in $\mu \mathrm{m}$ ) from CalceinAM staining using Simple Neurite Tracer (an ImageJ add-on software). The lengths of ten random neurites per image, 3 images per well, and 2 wells per experimental group were measured. The data are presented as a mean neurite length \pm SEM (in $\mu \mathrm{m}$ ) from 2 independent experiments. Statistical analysis was performed with one-way ANOVA with Tukey's post hoc test independently for each time point. $* * * P<0.05$, $* * P<0.01$, and $* * * P<0.001$ vs. vehicle-treated cells; ${ }^{\#} P<0.05$ vs. $\mathrm{H}_{2} \mathrm{O}_{2}$-treated cells 
To confirm the neuroprotective potential of Nec-1 in SH-SY5Y cells, we also used another oxidative stressbased model employing 6-OHDA. We observed a partial protection mediated by Nec-1 in UN-SH-SY5Y (20 and $40 \mu \mathrm{M})$ and RA-SH-SY5Y $(40 \mu \mathrm{M})$ cells (Table 1) against 6-OHDA-induced cell damage with a slight tendency towards a higher protection in the former cell type $(\mathrm{AUC}=24.64 \pm 4.15$ and $\mathrm{AUC}=14.11 \pm 2.91$ for $\mathrm{UN}$ - and RA-SH-SY5Y, respectively; $t$ test, $P=0.0968$ ).

\section{Neuroprotective Effects of Nec-1 Against Oxidative Stress-Induced Cell Damage in HT-22 Cells}

Twenty-four hours of treatment with Nec-1 at up to $40 \mu \mathrm{M}$ was safe for HT-22 cells (Fig. 4a). Nec-1 attenuated the HT-22 cell damage induced by $\mathrm{H}_{2} \mathrm{O}_{2}$ at concentrations of $20 \mu \mathrm{M}, 20$ $40 \mu \mathrm{M}$, and $10-40 \mu \mathrm{M}$ in the MTT reduction, LDH release, and PI staining assays, respectively (Fig. $4 \mathrm{a}-\mathrm{c}$ ). Moreover, Nec-1 significantly attenuated the Glu-evoked cell damage in the concentration range $10-40 \mu \mathrm{M}$ and that effect was similar to NAC-mediated protection (Fig. 4d).

\section{The Effect of Combined Treatment with Nec-1 and Caspase-3 Inhibitor in UN- and RA-SH-SY5Y Cells}

Since in our study we used the cell damage models connected with induction of apoptosis, and on the other hand we observed protective effects of necroptosis inhibitor Nec-1, we have speculated that combination of a caspase-3 inhibitor with Nec-1 could increase the extent of protection when compared with their effects when given separately. In UN- and RA-SH-SY5Y cells, we

Table 1 The effect of necrostatin-1 on 6-OHDA-induced cell damage in UN- and RA-SH-SY5Y cells

\begin{tabular}{|c|c|c|}
\hline & UN-SH-SY5Y & RA-SH-SY5Y \\
\hline Control & $99.9 \pm 0.1$ & $100.0 \pm 0.0$ \\
\hline 6-OHDA & $62.8 \pm 0.6^{* * *}$ & $68.6 \pm 0.2 * * *$ \\
\hline+ Nec-1 20 & $72.0 \pm 2.6^{* * *, \#}$ & $70.2 \pm 2.0 * * *$ \\
\hline+ Nec-1 40 & $78.2 \pm 5.6^{* * *}$ & $81.2 \pm 3.8^{* *, \#}$ \\
\hline$+\mathrm{NAC}$ & $81.4 \pm 4.7 * * *, \ldots \#$ & $83.2 \pm 4.0^{* *}, \#$ \\
\hline
\end{tabular}

UN- and RA-SH-SY5Y cells were pre-treated for 30 min with necrostatin-1 (Nec-1; 20 and $40 \mu \mathrm{M})$ followed by $24 \mathrm{~h}$ of treatment with 6-hydroxydopamine (6-OHDA, 0.1 and $0.2 \mathrm{mM}$ for UN- and RA-SHSY5Y cells, respectively)

An antioxidant $\mathrm{N}$-acetylcysteine (NAC, $1 \mathrm{mM}$ ) was given to cells concomitantly with 6-OHDA. The MTT reduction assay was employed for cell viability assessment

Data were normalized to the vehicle-treated cells and are presented as the mean \pm SEM from 4 separate experiments with 5 repetitions each

$* * P<0.01$ and $* * * P<0.001$ vs. vehicle-treated cells

${ }^{\#} P<0.05,{ }^{\# \#} P<0.01$, and ${ }^{\# \#} P<0.001$ vs. 6-OHDA-treated cells observed a similar range of protection mediated by Nec1 and Ac-DEVD-CHO against $\mathrm{H}_{2} \mathrm{O}_{2}$-evoked cell damage when drugs were administrated separately which has not been changed after combined treatment with both protectants (Fig. 5a, b). We obtained similar results in the model of 6-OHDA-induced UN-SH-SY5Y cell damage (Fig. 6a). In RA-SH-SY5Y cells, we also observed that Nec-1 attenuated the cell injury evoked by $6-\mathrm{OHDA}$ and that this effect was not changed by combined treatment with caspase- 3 inhibitor. The latter compound was not protective in this cell phenotype (Fig. 6b).

\section{The Effect of Combined Treatment with Nec-1 and Curcumin in UN- and RA-SH-SY5Y Cells}

In UN-SH-SY5Y cells, curcumin $(5 \mu \mathrm{M})$ and Nec-1 $(40 \mu \mathrm{M})$ were protective against $\mathrm{H}_{2} \mathrm{O}_{2}$ - or 6-OHDA-evoked cell damage to the same extent when given separately or in combination (Figs. 5c and 6c). However, in RA-SH-SY5Y we observed a significantly higher protection of combined treatment with both agents when compared with the effect of each compound given alone in the model of $\mathrm{H}_{2} \mathrm{O}_{2}$-induced cell damage (Fig. 5d) but not in 6-OHDA one (Fig. 6d). It should be noted that Curc $(5 \mu \mathrm{M})$ was not protective in RA-SH-SY5Y cells against $\mathrm{H}_{2} \mathrm{O}_{2}$ - or 6-OHDA-evoked cell damage when given alone (Figs. $5 \mathrm{~d}$ and $6 \mathrm{~d}$ ).

\section{The Effect of Combined Treatment with Nec-1 and Caspase Inhibitor in HT-22 Cells}

The $\mathrm{H}_{2} \mathrm{O}_{2}$-evoked HT-22 cell damage was attenuated by Nec-1 $(20 \mu \mathrm{M})$ but not by the caspase inhibitor, Z-VADfmk $(20 \mu \mathrm{M})$ (Fig. 7a). Unexpectedly, the latter agent inhibited the Nec-1-mediated protection (Fig. 7a). Similar results we found in the model of Glu-induced cell damage (Fig. 7b).

\section{Neuroprotection Mediated by Nec-1 in SH-SY5Y Cells Is Not Connected with Caspase-3 Inhibition}

Since our previous studies showed an involvement of caspase3 activation in detrimental effects of $\mathrm{H}_{2} \mathrm{O}_{2}$ in SH-SY5Y cells (Chwastek et al. 2017; Jantas et al. 2015a), and on the other hand there are data showing the effect of Nec-1 on caspase-3 activity in some models of neuronal cell injury (Wang et al. 2014; Yang et al. 2017a, b), we decided to check the effect of Nec-1 on caspase- 3 activity in our study. We showed an activation of caspase- 3 in the model of $\mathrm{H}_{2} \mathrm{O}_{2}$-evoked cell damage in UN- and RA-SH-SY5Y cells which has been totally prevented by caspase-3 inhibitor Ac-DEVD-CHO but was not affected by Nec-1 (1-20 $\mu \mathrm{M})$ (Table 2). We further confirmed a lack of involvement of caspase- 3 inhibition in neuroprotection mediated by Nec-1 against $\mathrm{H}_{2} \mathrm{O}_{2}$ by Western blot 

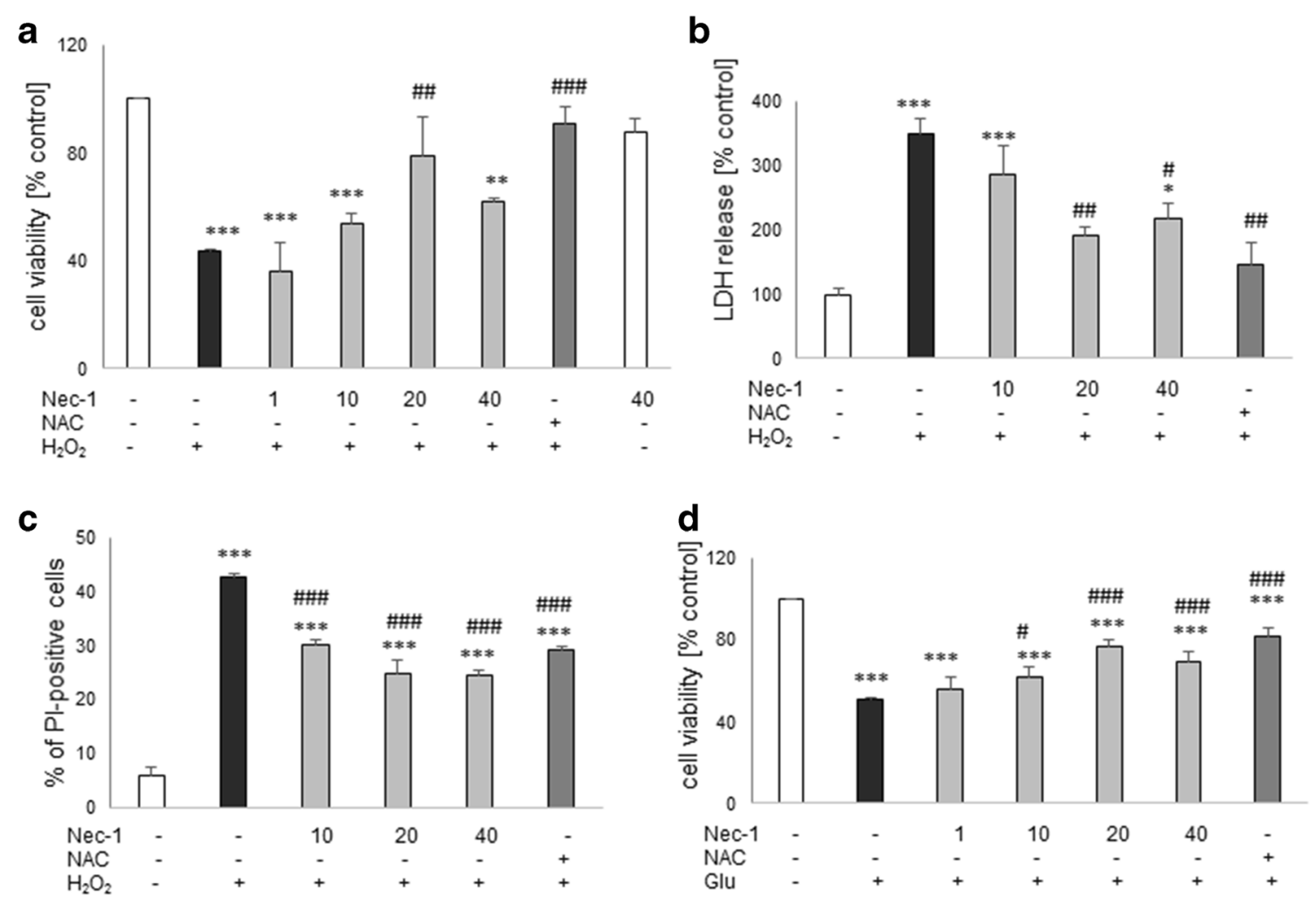

Fig. 4 The effect of necrostatin- 1 on $\mathrm{H}_{2} \mathrm{O}_{2-}(\mathbf{a}-\mathbf{c})$ or glutamate- (Glu, d) induced cell damage in hippocampal HT-22 cells. The cells were pretreated for 30 min with necrostatin-1 (Nec-1; $1-40 \mu \mathrm{M})$ followed by $24 \mathrm{~h}$ of treatment with $\mathrm{H}_{2} \mathrm{O}_{2}(1 \mathrm{mM})$ or Glu $(3 \mathrm{mM})$. As a positive control for the assays, we used antioxidant $\mathrm{N}$-acetylcysteine (NAC, $1 \mathrm{mM}$ ) which was given concomitantly with the cell damaging factors. $\mathbf{a}, \mathbf{d}$ Results of cell viability assessment in the model of cell damage induced by $\mathrm{H}_{2} \mathrm{O}_{2}$ (a) and Glu (d) measured by the MTT reduction assay. Data were normalized to vehicle-treated cells (control) and are presented as the mean \pm SEM from 3 to 10 separate experiments with 5 repetitions each. b Results

of cell toxicity assessment in HT-22 cell exposed to $\mathrm{H}_{2} \mathrm{O}_{2}$ and Nec-1 measured by the LDH release assay. Data were normalized to vehicletreated cells (control) and are presented as the mean \pm SEM from 3 to 5 separate experiments with 5 repetitions each. $\mathbf{c}$ Flow cytometry results of propidium iodide (PI)-stained HT-22 cells after $24 \mathrm{~h}$ of cell treatment with $\mathrm{H}_{2} \mathrm{O}_{2}$ and Nec-1. Data are presented as the mean \pm SEM of PI-positive cells from 3 to 4 independent experiments with 2 replicates. $* P<0.05$, $* * P<0.01$, and $* * * P<0.001$ vs. vehicle-treated cells; ${ }^{*} P<0.05$, ${ }^{\# \#} P<0.01$, and ${ }^{\# \# \#} P<0.001$ vs. $\mathrm{H}_{2} \mathrm{O}_{2}$ - or Glu-treated cells

analysis of $120 \mathrm{kDa}$ spectrin $\alpha$ II breakdown product which is specifically cleaved by caspases (Fig. 8a, b).

Looking for possible mechanisms responsible for synergistic effect of Nec-1 and curcumin against the $\mathrm{H}_{2} \mathrm{O}_{2}$-induced cell damage, we checked caspase- 3 and caspase- 1 activities in RA-SH-SY5Y cells. The $\mathrm{H}_{2} \mathrm{O}_{2}$-induced caspase-3 activity after $18 \mathrm{~h}$ of treatment was not attenuated by Curc $(5 \mu \mathrm{M})$ alone or in combination with Nec-1 $(20 \mu \mathrm{M})$ (data not shown). However, we found an increase in caspase- 1 activity after 18 but not after $9 \mathrm{~h}$ of treatment of RA-SH-SY5Y cells with $\mathrm{H}_{2} \mathrm{O}_{2}$ $(0.5 \mathrm{mM})$ which was significantly attenuated by combined treatment with Nec-1 and Curc, but not when the agents were given separately (Table 3 ).

\section{Neuroprotection Mediated by Nec-1 Is Not Connected with Inhibition of Calpains or Caspase-3-Independent Mechanism Engaging AIF Translocation}

Since calpains, calcium-dependent intracellular proteases, have been reported to participate in the mechanisms of

$\mathrm{H}_{2} \mathrm{O}_{2}$-evoked neuronal cell damage (Chwastek et al. 2017; Jantas et al. 2015a), we measured by Western blot the protein level of $145 \mathrm{kDa}$ spectrin $\alpha$ II breakdown product, which is specifically cleaved by calpains. Our data showed a significant increase in calpain activity after $14 \mathrm{~h}$ treatment with $\mathrm{H}_{2} \mathrm{O}_{2}$ in UN- and RA-SH-SY5Y, which has been attenuated by calpain inhibitor MDL28170 $(10 \mu \mathrm{M})$ but not influenced by Nec-1 $(20 \mu \mathrm{M})$ (Fig. 8a, b).

Based on our previous findings where we showed an engagement of caspase- 3 independent mechanism engaging AIF translocation in the model of $\mathrm{H}_{2} \mathrm{O}_{2}$-evoked cell damage in UN-SH-SY5Y cells (Jantas et al. 2015a), and on the other hand, there are data showing a connection between AIF translocation and necroptosis induction (Bollino et al. 2015; Ji et al. 2011; Xu et al. 2010b, 2016), we decided to study the effect of Nec-1 $(20 \mu \mathrm{M})$ on cytosolic AIF protein level. We observed almost twofold increase in cytosolic AIF level after $14 \mathrm{~h}$ of treatment of UN-SH-SY5Y cells with $\mathrm{H}_{2} \mathrm{O}_{2}(0.25 \mathrm{mM})$ which confirms our previous data (Jantas et al. 2015a); however, this effect was not changed by Nec-1 (20 $\mu \mathrm{M})$ (Fig. 8c). 
a

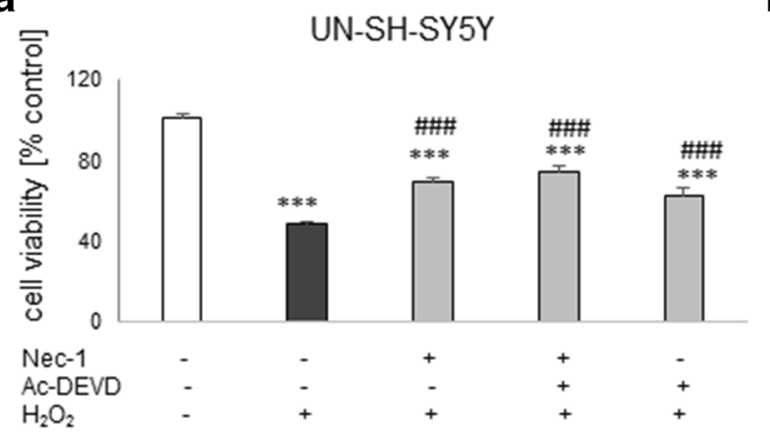

C

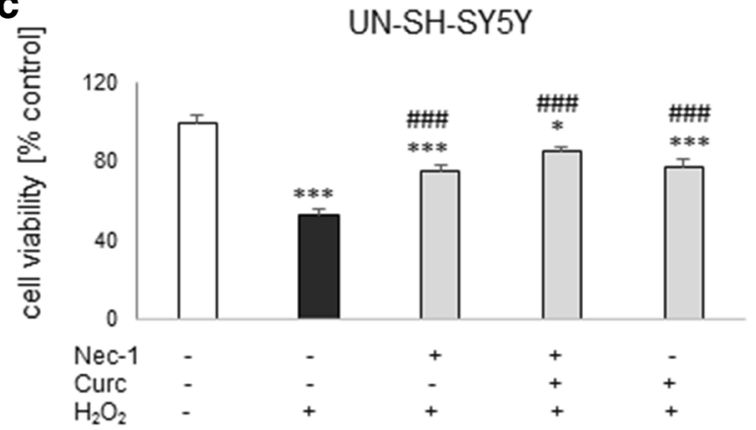

b

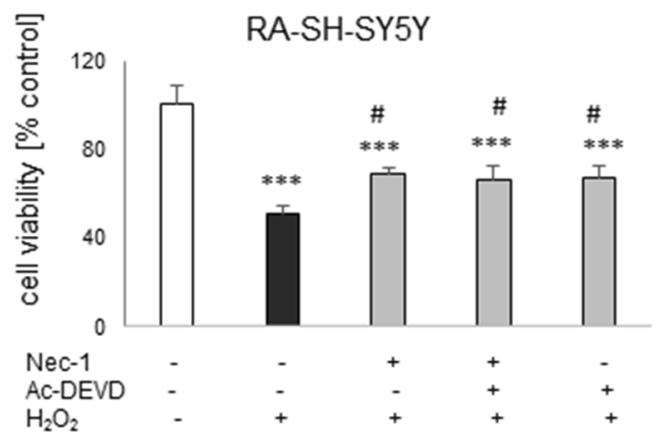

d

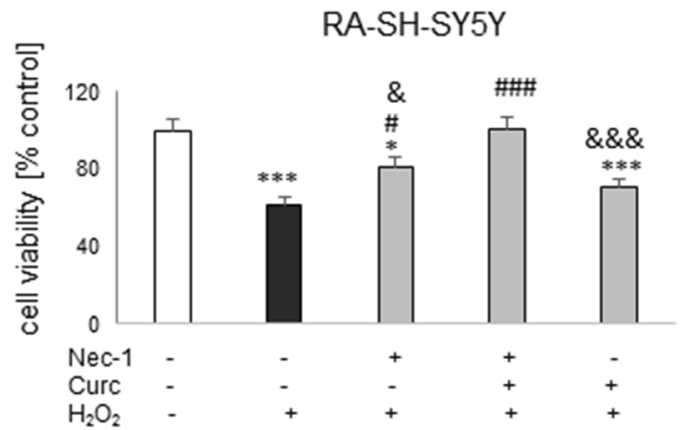

Fig. 5 The effect of combined treatment with necrostatin-1 (Nec-1) and caspase-3 inhibitor (Ac-DEVD-CHO) (a, b) or Nec-1 and curcumin (Curc) against the hydrogen peroxide-induced cell damage in UN- (a, c) and RA- (b, d) SH-SY5Y cells. The cells were pre-treated for $30 \mathrm{~min}$ with Nec-1 $(20 \mu \mathrm{M})$ and Ac-DEVD-CHO $(20 \mu \mathrm{M})$ or Nec-1 $(20 \mu \mathrm{M})$ and Curc $(5 \mu \mathrm{M})$ alone or in combination followed by $24 \mathrm{~h}$ of treatment with $\mathrm{H}_{2} \mathrm{O}_{2}(0.25 \mathrm{mM}$ and $0.5 \mathrm{mM}$ for UN- and RA-SH-SY5Y cells). Cell

\section{Neuroprotection Mediated by Nec-1 Against $\mathrm{H}_{2} \mathrm{O}_{2}$-Evoked Cell Damage in UN- and RA-SH-SY5Y Cells Is Connected with Cathepsin D Inhibition}

Based on our previous findings where we showed an involvement of cathepsin $\mathrm{D}$ activation in the cell damaging effect of $\mathrm{H}_{2} \mathrm{O}_{2}$ in RA-SH-SY5Y cells (Chwastek et al. 2017), we decided to check if the inhibition of this enzyme could be involved in the neuroprotective effect of Nec-1. We observed an almost three- and twofold increase in cathepsin D activity after $18 \mathrm{~h}$ of treatment with $\mathrm{H}_{2} \mathrm{O}_{2}(0.25$ and $0.5 \mathrm{mM}$ for UN- and RA-SH-SY5Y cells, respectively) which was completely blocked by cathepsin D inhibitor, pepstatin A $(0.2 \mu \mathrm{M})$ (Fig. 9a, b). Nec-1 significantly attenuated the $\mathrm{H}_{2} \mathrm{O}_{2}$-evoked cathepsin D activity at concentrations of $10-20 \mu \mathrm{M}$ and $20-40 \mu \mathrm{M}$ for UN- and RASHSY5Y cells, respectively (Fig. 9a, b). We also checked the cathepsin D protein level by WB method; however, we did not find any significant changes in 43 and $33 \mathrm{kDa}$ cathepsin D forms after $18 \mathrm{~h}$ of treatment with $\mathrm{H}_{2} \mathrm{O}_{2}$ and Nec-1 in UN- and RA-SH-SY5Y cells (Fig. 9c, d).

Next, we compared the level of protection mediated by Nec-1 $(20 \mu \mathrm{M})$ or PsA $(0.2 \mu \mathrm{M})$ when given separately or viability was estimated by the MTT reduction assay, and data were normalized to vehicle-treated cells (control) and are presented as the mean \pm SEM from 3 separate experiments with 5 repetitions each. $* P<0.05$ and *** $P<0.001$ vs. vehicle-treated cells; ${ }^{\#} P<0.05$ and ${ }^{\# \# \#} P<0.001$ vs. $\mathrm{H}_{2} \mathrm{O}_{2}$-treated cells; ${ }^{\&} P<0.05$ and ${ }^{\& \& \&} P<0.001$ vs. $\mathrm{H}_{2} \mathrm{O}_{2}+\mathrm{Nec}-1+$ Curc-treated cells

in combination in the model of $\mathrm{H}_{2} \mathrm{O}_{2}$-evoked cell death in UN-SH-SY5Y cells. The protection mediated by Nec-1 was comparable with the effect of PsA which was not changed after combined treatment with both inhibitors as estimated by the MTT reduction and LDH release assays (Table 4).

\section{Discussion}

The present study confirmed that SH-SY5Y cell culture is a reliable in vitro model for studying the mechanism of neurotoxicity, and that undifferentiated SH-SY5Y cells are more prone to the effects of cell damaging compounds than the differentiated ones (Chwastek et al. 2017; Jantas et al. 2014b, 2015b, 2018b; Wenker et al. 2010). We found that 30 min pre-treatment of the SH-SY5Y cells with Nec-1 in a wide range of micromolar concentrations attenuated but not totally prevented toxic effects of $\mathrm{H}_{2} \mathrm{O}_{2}$ or 6-OHDA suggesting that necroptosis could be only one of several activated cell death signaling pathways following exposure of the cells to the above-mentioned toxic agents. Indeed, it was reported that caspase-3-dependent apoptosis and necrosis were also involved in the mechanism of $\mathrm{H}_{2} \mathrm{O}_{2}$ neurotoxicity (Chwastek et al. 2017; Cole and Perez-Polo 2002; Jantas et al. 2015a; 

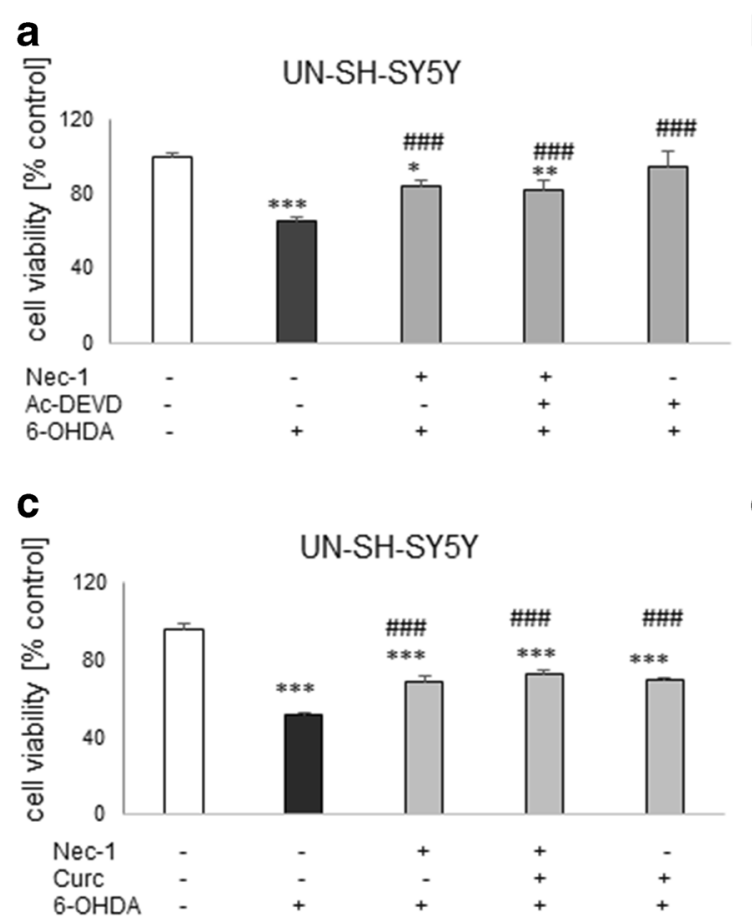

Fig. 6 The effect of combined treatment with necrostatin-1 (Nec-1) and caspase-3 inhibitor (Ac-DEVD-CHO) $(\mathbf{a}, \mathbf{b})$ or Nec-1 and curcumin (Curc) (c, d) against the 6-OHDA-induced cell damage in UN- (a, c) and RA- (b, d) SH-SY5Y cells. The cells were pre-treated for $30 \mathrm{~min}$ with Nec-1 $(20 \mu \mathrm{M})$ and Ac-DEVD-CHO $(20 \mu \mathrm{M})$ or Nec-1 $(20 \mu \mathrm{M})$ and Curc $(5 \mu \mathrm{M})$ alone or in combination followed by $24 \mathrm{~h}$ of treatment with

Park et al. 2016), which was also confirmed in our present study by measurement of apoptotic and necrotic markers, caspase-3 activity, and PI staining, respectively (Fig. 1, Table 2). We also found protection mediated by Nec-1 in another model of oxidative stress (6-OHDA) in UN- and RA-SH-SY5Y cells (Table 1), which confirms previous findings from PC12 cells (Wu et al. 2015), but that effect was relatively smaller than against $\mathrm{H}_{2} \mathrm{O}_{2}$. It could probably be explained by the predominant role of apoptotic processes in 6-OHDA-induced cytotoxicity in SH-SY5Y cells (No et al. 2010; Park et al. 2014). Our study showed that the protective effect of Nec-1 against $\mathrm{H}_{2} \mathrm{O}_{2}$ was quantitatively similar to the effect of the specific caspase-3 inhibitor (Ac-DEVD-CHO) in both SH-SY5Y cell phenotypes, although no synergy after concomitant treatment with the both agents could be observed (Figs. 5a, b and 6a). Similar results were obtained in the 6OHDA model but only in UN-SH-SY5Y cells, since in differentiated ones we did not find protection by a caspase-3 inhibitor (Fig. 6b). The above findings suggest a link between apoptotic and necroptotic machinery at least in SH-SY5Y cells exposed to oxidative stress stimulus since in another cell damage model of neuroblastoma cells (induced by stenodactylin) there was a complete prevention of cell death by combined treatment with caspase inhibitor (Z-VAD-fmk) plus catalase or Nec-1 (Polito et al. 2016). Our data from SHSY5Y cells are in contrast to results of previous study where b

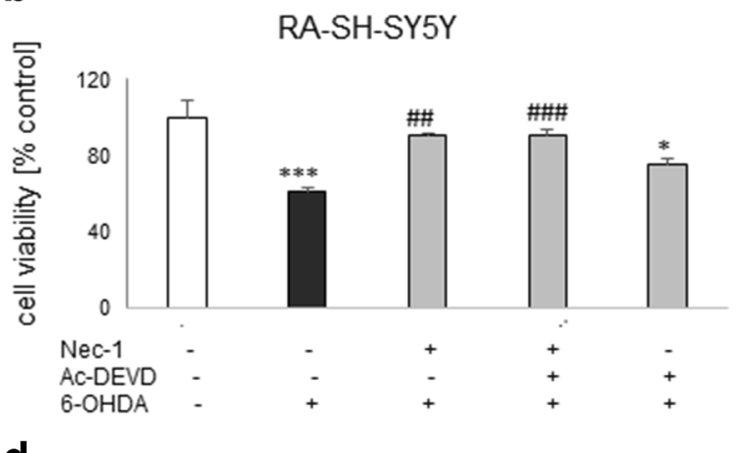

d

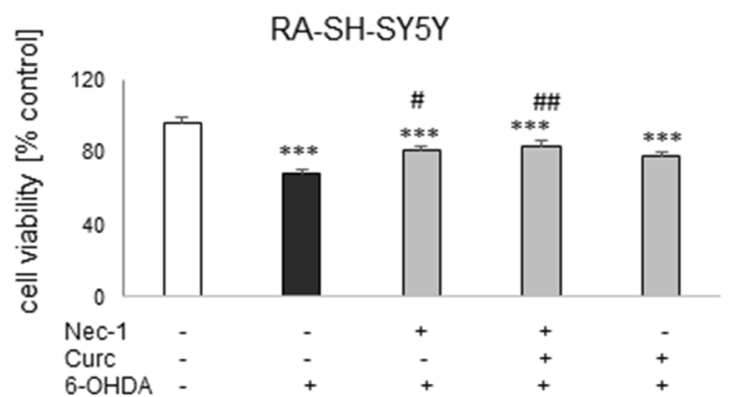

6-OHDA ( 0.1 and $0.2 \mathrm{mM}$ for UN- and RA-SH-SY5Y cells, respectively). Cell viability was estimated by the MTT reduction assay, and data were normalized to vehicle-treated cells (control) and are presented as the mean \pm SEM from 3 separate experiments with 5 repetitions each. $* P<0.05, * * P<0.01$, and $* * * P<0.001$ vs. vehicle-treated cells; ${ }^{\#} P<0.05,{ }^{\#} P<0.01$, and ${ }^{\# \# \#} P<0.001$ vs. $\mathrm{H}_{2} \mathrm{O}_{2}$-treated cells

Nec-1 $(40 \mu \mathrm{M})$ but not pan-caspase inhibitor (Z-VAD-fmk) attenuated cell damage induced by $\mathrm{H}_{2} \mathrm{O}_{2}$ in neuroblastoma SK-N-SH cells (Lee et al. 2011). Similar results we obtained in HT-22 cells where Nec-1 but not the caspase inhibitor was protective against $\mathrm{H}_{2} \mathrm{O}_{2}$ or Glu-induced cell damage (Fig. 4) suggesting a cell-specific mechanisms of Nec-1 protective action. Moreover, in HT-22 cells, Z-VAD-fmk inhibited protection induced by Nec-1 after concomitant treatment which confirms data obtained by Xu et al. (2007) at least for the model of Glu-evoked oxytosis. However, we found an opposite effect in the $\mathrm{H}_{2} \mathrm{O}_{2}$-induced cell death model, since in the paper by $\mathrm{Xu}$ et al. (2007) they did not show Nec-1-elicited protection against oxidative stress $\left(\mathrm{H}_{2} \mathrm{O}_{2}\right.$ or menadione)-induced cell damage. Nec-1 was also not protective against $\mathrm{H}_{2} \mathrm{O}_{2}$-induced cell damage in oligodendrocyte precursors (Kim et al. 2010). It is not excluded that at a shorter time of exposure to oxidative stressors ( $8 \mathrm{~h}$ ) used by Xu et al. (2007) the mechanisms of cell death of HT-22 cells are more necrotic and thus not affected by $\mathrm{Nec}-1$, whereas in our model with $24 \mathrm{~h}$ of treatment, there was the situation of necroptosis induction which could be prevented by Nec-1. Although there are some reports showing the involvement of autophagy in the $\mathrm{H}_{2} \mathrm{O}_{2}$-evoked cell damage of SH-SY5Y cells (Castino et al. 2010, 2011), our unpublished data showed no autophagy induction after hydrogen peroxide treatment in UN-SH-SY5Y cells (at least when measured by WB analysis of LC3 II, p62, and Beclin-1 levels after 

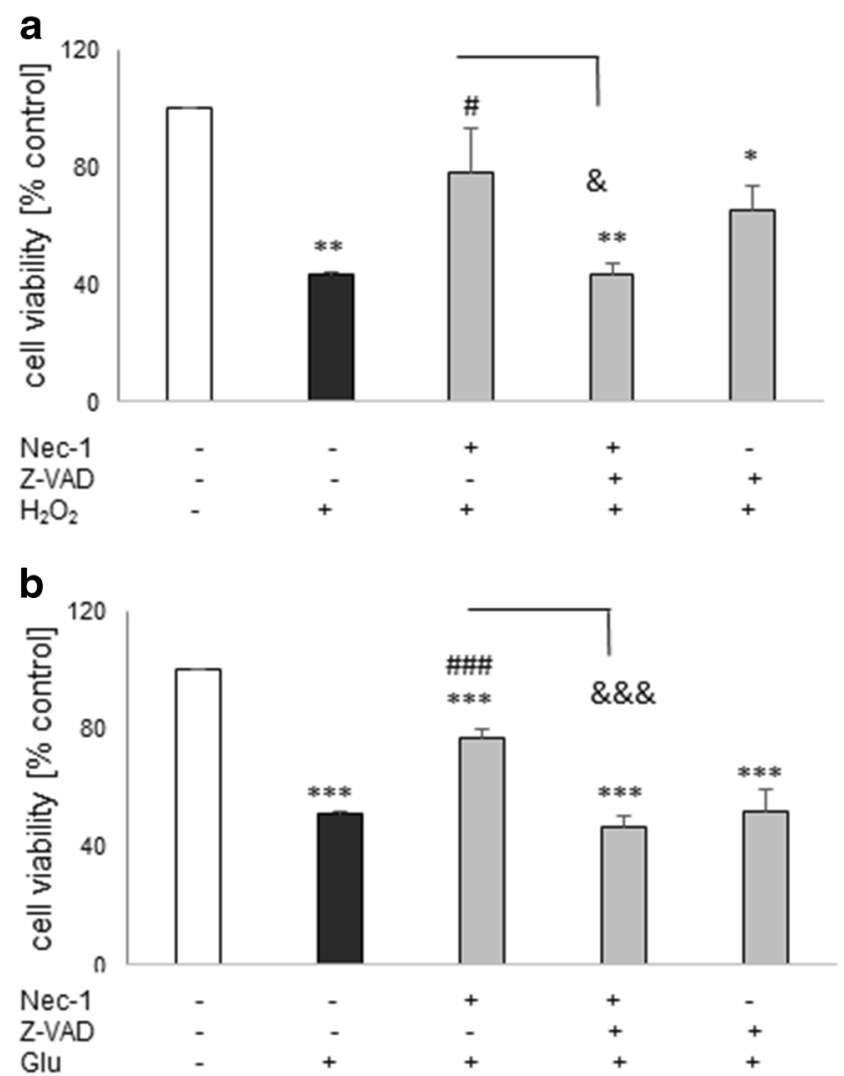

Fig. 7 The effect of combined treatment with necrostatin-1 (Nec-1) and pan-caspase inhibitor (Z-VAD-fmk) against the $\mathrm{H}_{2} \mathrm{O}_{2}$ - (a) and glutamate(Glu, b) induced cell damage in HT-22 cells. The cells were pre-treated for 30 min with Nec-1 $(20 \mu \mathrm{M})$ and Z-VAD-fmk $(20 \mu \mathrm{M})$ alone or in combination followed by $24 \mathrm{~h}$ of treatment with $\mathrm{H}_{2} \mathrm{O}_{2}(1 \mathrm{mM})$ or Glu $(3 \mathrm{mM})$. Cell viability was estimated by the MTT reduction assay, and data were normalized to vehicle-treated cells (control) and are presented as the mean \pm SEM from 3 to 7 separate experiments with 5 repetitions each. $* P<0.05$, $* * P<0.01$, and $* * * P<0.001$ vs. vehicle-treated cells; ${ }^{\#} P<0.05$ and ${ }^{\# \# \#} P<0.001$ vs. $\mathrm{H}_{2} \mathrm{O}_{2}$ - or Glu-treated cells; ${ }^{\&} P<0.05$ and \&\&\& $P<0.001$ vs. $\mathrm{H}_{2} \mathrm{O}_{2}+\mathrm{Nec}-1$ or Glu $+\mathrm{Nec}-1$-treated cells

9,18 , or $24 \mathrm{~h}$ after cell treatment). The differences between our results and Castino et al. $(2010,2011)$ findings could be explained by different concentrations of $\mathrm{H}_{2} \mathrm{O}_{2}$ used (250 $\mu \mathrm{M}$ and $50-100 \mu \mathrm{M}$, respectively) as well as culture medium content (DMEM with high glucose with $1 \%$ FBS vs. $50 \%$ minimal essential medium and 50\% F12 nutrient medium supplemented with $10 \%$ FBS, respectively). All these factors could significantly influence the type of induced cell death program after the same stimulus. Since autophagy inhibition has been linked with Nec-1 neuroprotection mediated against 6-OHDA-evoked cell damage in rat PC12 cells (Wu et al. 2015), it is not excluded that this process could be also engaged in the protection against this neurotoxin in human SH-SY5Y cells.

In our study, we showed for the first time that neuroprotection mediated by Nec-1 was higher in undifferentiated than RA-differentiated SH-SY5Y cells at least when AUC values in cell viability assay were compared. This effect was more pronounced in the model of $\mathrm{H}_{2} \mathrm{O}_{2}$-induced cell damage than 6-OHDA-induced injury. Moreover, the non-specific apoptosis and necroptosis inhibitor curcumin significantly augmented beneficial effect of Nec-1 against $\mathrm{H}_{2} \mathrm{O}_{2}$, though in RA-SHSY5Y cells only. The above facts suggest that the interplay between necroptosis and apoptosis depends on the differentiation state of the cell culture and that some mechanisms of Nec-1 neuroprotective action could be masked by differentiation of cells with retinoic acid (e.g., activation of PI3-K/Akt and MAPK/ERK1/2 pro-survival pathways) (Cheung et al. 2009; Lopes et al. 2010; Wenker et al. 2010). The higher basal and stimulated caspase-3 activity in UN-SH-SY5Y cells, shown by us, also supports anti-apoptotic phenotype of RASH-SY5Y cells. It is also corroborated by our observation of the lack of neuroprotective effect of a caspase-3 inhibitor or

Table 2 The effect of necrostatin1 on hydrogen peroxide-induced caspase-3 activity in UN- and RA-SH-SY5Y cells

\begin{tabular}{llll}
\hline & $\begin{array}{l}\text { UN-SH-SY5Y } \\
9 \mathrm{~h}\end{array}$ & $\begin{array}{l}\text { RA-SH-SY5Y } \\
9 \mathrm{~h}\end{array}$ & $\begin{array}{l}\text { RA-SH-SY5Y } \\
18 \mathrm{~h}\end{array}$ \\
\hline Control & $100.0 \pm 8.0$ & $100.0 \pm 2.7$ & $100.0 \pm 5.8$ \\
$\mathrm{Nec}-120$ & $95.9 \pm 0.3$ & $109.3 \pm 5.2$ & $119.8 \pm 5.9$ \\
$\mathrm{H}_{2} \mathrm{O}_{2}$ & $753.8 \pm 20.5 * * *$ & $229.6 \pm 18.9 * * *$ & $487.9 \pm 44.9 * * *$ \\
$+\mathrm{Nec}-11$ & $854.7 \pm 31.5 * * *$ & $236.9 \pm 5.8 * *$ & $668.0 \pm 64.3 * * *$ \\
$+\mathrm{Nec}-110$ & $746.1 \pm 39.2 * * *$ & $252.9 \pm 12.2 * * *$ & $568.1 \pm 52.8 * * *$ \\
$+\mathrm{Nec}-120$ & $760.9 \pm 19.8 * * *$ & $271.9 \pm 8.2 * * *$ & $520.1 \pm 27.5 * * *$ \\
+ Ac-DEVD-CHO & $33.5 \pm 1.1$ & $24.0 \pm 14.0$ \#\#\# & $19.9 \pm 8.9$ \#\#\# \\
\hline
\end{tabular}

UN- and RA-SH-SY5Y cells were pre-treated for 30 min with necrostatin-1 (Nec-1; 1-20 $\mu \mathrm{M}$ ) followed by 9 or $18 \mathrm{~h}$ of treatment with $\mathrm{H}_{2} \mathrm{O}_{2}(0.25$ and $0.5 \mathrm{mM}$ for UN- and RA-SH-SY5Y, respectively)

As a positive control for the assay we used Ac-DEVD-CHO $(20 \mu \mathrm{M})$, an inhibitor of caspase- 3 which was given 30 min before the cell damaging factor

Data were normalized to vehicle-treated cells (control) and are presented as the mean \pm SEM from 3 separate experiments with 2 repetitions each

$* * P<0.01$ and $* * * P<0.001$ vs. vehicle-treated cells

\#\#\# $P<0.001$ vs. $\mathrm{H}_{2} \mathrm{O}_{2}$-treated cells 
a
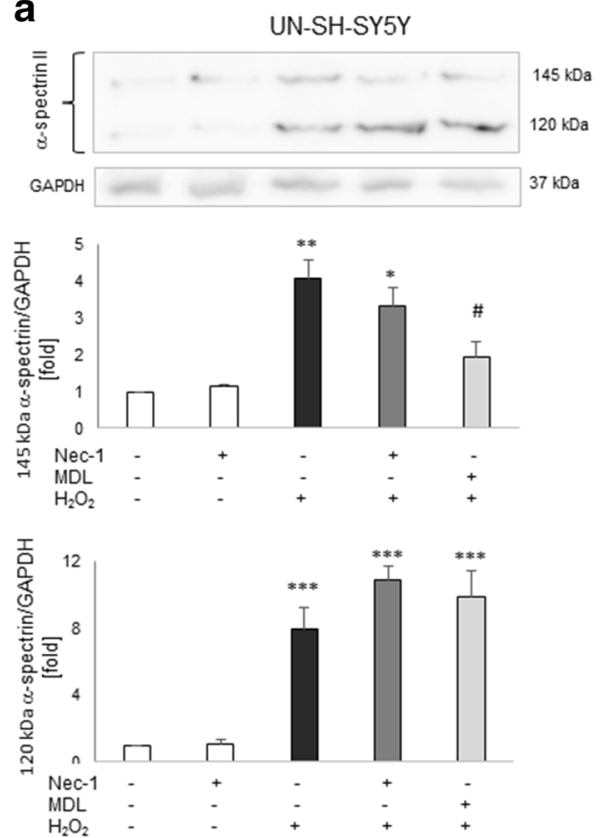

b
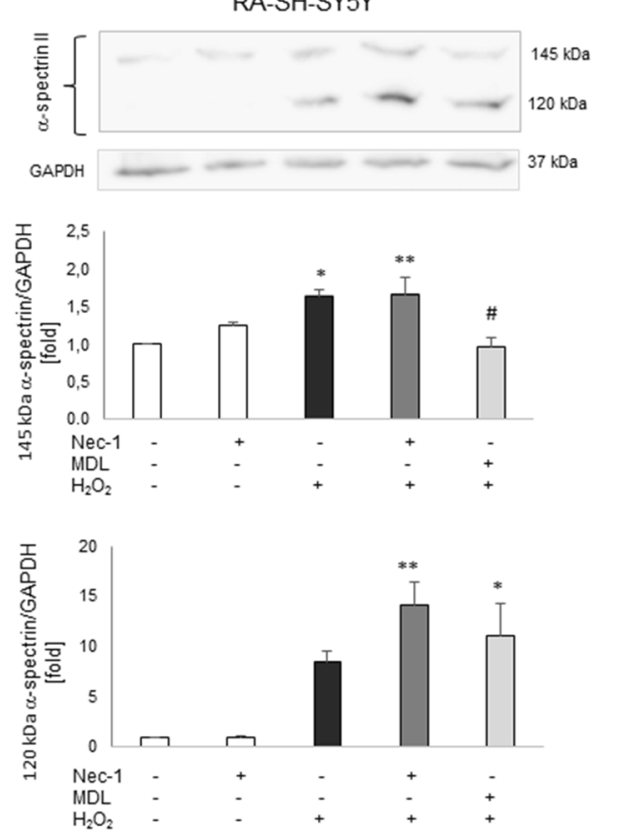

C UN-SH-SYSY
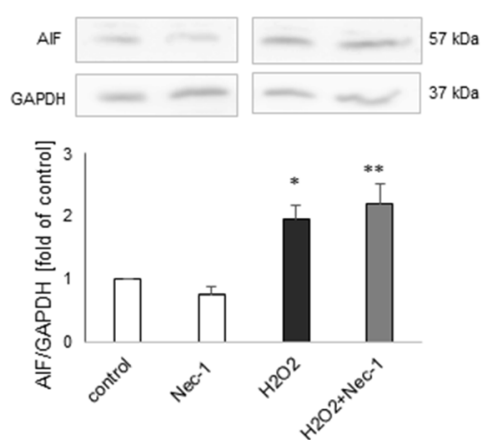

Fig. 8 a, b The effect of necrostatin- 1 (Nec-1) on the $\mathrm{H}_{2} \mathrm{O}_{2}$-induced $145 \mathrm{kDa}$ and $120 \mathrm{kDa}$ spectrin $\alpha$ II breakdown products in UN- and RA-SH-SY5Y cells, which are specifically cleaved by calpains and caspases, respectively. Cells were pre-treated for $30 \mathrm{~min}$ with $\mathrm{Nec}-1$ $(20 \mu \mathrm{M})$ or calpain inhibitor MDL28170 $(10 \mu \mathrm{M})$, followed by $14 \mathrm{~h}$ of treatment with $\mathrm{H}_{2} \mathrm{O}_{2}(0.25$ and $0.5 \mathrm{mM}$ for $\mathrm{UN}$ - and RA-SH-SY5Y cells, respectively). c The effect of Nec-1 on the $\mathrm{H}_{2} \mathrm{O}_{2}$-induced increase in cytosolic AIF (apoptosis inducing factor) level. The UN-SH-SY5Y cells

curcumin in RA-SH-SY5Y cells against 6-OHDA-evoked cell damage, which is the cell death model connected rather

Table 3 The effect of necrostatin- 1 and curcumin alone and in combination against the hydrogen peroxide-induced caspase-1 activity in RASH-SY5Y cells

\begin{tabular}{lll}
\hline & $\begin{array}{l}9 \mathrm{~h} \\
(\% \text { control })\end{array}$ & $\begin{array}{l}18 \mathrm{~h} \\
(\% \text { control })\end{array}$ \\
\hline Control & $100.0 \pm 0.8$ & $100.0 \pm 6.4$ \\
$\mathrm{H}_{2} \mathrm{O}_{2}$ & $93.7 \pm 8.3$ & $171.5 \pm 15.8 * * *$ \\
$+\mathrm{Nec}-1$ & $107.6 \pm 3.7$ & $143.6 \pm 9.5 *$ \\
+ Curc & $114.8 \pm 8.1$ & $135.1 \pm 3.9$ \\
+ Nec-1 + Curc & $116.3 \pm 2.6$ & $128.8 \pm 5.5^{\#}$ \\
+ Inh cas-1 & $73.9 \pm 6.8$ & $42.6 \pm 4.3 * * \# \#$ \\
\hline
\end{tabular}

RA-SH-SY5Y cells were pre-treated for 30 min with necrostatin-1 (Nec$1 ; 20 \mu \mathrm{M}$ ) followed by $24 \mathrm{~h}$ of treatment with curcumin (Curc, $5 \mu \mathrm{M}$ ) and $\mathrm{H}_{2} \mathrm{O}_{2}(0.5 \mathrm{mM})$

As a positive control for the assay we used Ac-YVAD-CHO $(20 \mu \mathrm{M})$, an inhibitor of caspase-1 which was given $30 \mathrm{~min}$ before the cell damaging factor

Data were normalized to the vehicle-treated cells and are presented as the mean \pm SEM from 2 separate experiments with 2 repetitions each

$* P<0.05$, *** $P<0.01$, and $* * * P<0.001$ vs. vehicle-treated cells

${ }^{\#} P<0.05$ and ${ }^{\# \#} P<0.001$ vs. $\mathrm{H}_{2} \mathrm{O}_{2}$-treated cells were pre-treated for $30 \mathrm{~min}$ with Nec-1 $(20 \mu \mathrm{M})$ followed by $14 \mathrm{~h}$ of treatment with $\mathrm{H}_{2} \mathrm{O}_{2}(0.25 \mathrm{mM})$. a-c Histograms show the quantified Western blot results from duplicate determinations in 2-3 independent experiments which were normalized to the protein loading control $(\mathrm{GAPDH})$ and are expressed as fold of the control \pm SEM. $* P<0.05$, $* * P<0.01$, and $* * * P<0.001$ vs. vehicle-treated cells; ${ }^{\#} P<0.05$ vs. $\mathrm{H}_{2} \mathrm{O}_{2}$-treated cells

with apoptotic than necrotic processes that are saturated after differentiation with RA (Cheung et al. 2009; No et al. 2010; Park et al. 2014). Our results obtained in UN-SH-SY5Y cells confirmed previous findings on neuroprotective effect of curcumin which could be mediated by its antioxidant, antiapoptotic, and anti-inflammatory mechanisms (Mhillaj et al. 2019; Sang et al. 2018; Uğuz et al. 2016).

The main finding of this study is the first observation that Nec-1 attenuating effect on hydrogen peroxide-induced SHSY5Y cell damage is associated with the inhibition of cathep$\sin$ D (Fig. 9) but not caspase-3 or calpain activities (Table 2, Fig. 8a, b). Cathepsin $\mathrm{D}$ is a lysosomal protease which plays a pivotal role in protein catabolism, having an impact on several pathophysiological processes, such as organ development, neurodegeneration, or cancer (Follo et al. 2007). Elevated ROS level could increase permeability of lysosomes and thus can promote release of cathepsins into cytoplasm leading to activation of various cell death programs (e.g., apoptosis) (Castino et al. 2007; Follo et al. 2007). Human cathepsin D is synthesized as a precursor of approximately $53 \mathrm{kDa}$ that is processed by proteolysis first into an intermediate single-chain of $48 \mathrm{kDa}$ and eventually into the mature double-chain form (Crabtree et al. 2014; Follo et al. 2007). It should be noted that in our study, the inhibitory action of Nec-1 on cathepsin D was present in UN- and RA-SH-SY5Y cells and the basal activity 


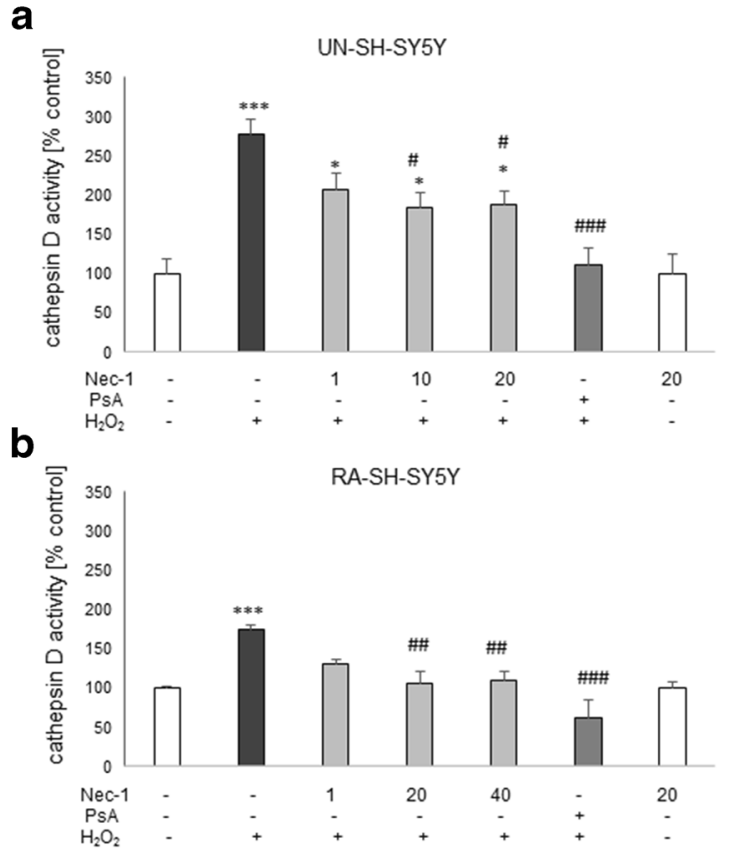

Fig. 9 a, b The effect of necrostatin- 1 (Nec-1) on $\mathrm{H}_{2} \mathrm{O}_{2}$-induced cathepsin D activity in UN- (a) and RA (b) SH-SY5Y cells. The cells were pretreated for 30 min with Nec-1 $(1-40 \mu \mathrm{M})$ or pepstatin A (PsA; $0.2 \mu \mathrm{M})$ followed by $18 \mathrm{~h}$ of treatment with $\mathrm{H}_{2} \mathrm{O}_{2}(0.25$ and $0.5 \mathrm{mM}$ for $\mathrm{UN}$ - and RA-SH-SY5Y cells, respectively). Data from duplicate determinations in 3-4 independent experiments were normalized to the protein level and are expressed as percentages of the control \pm SEM. c, d The effect of necrostatin-1 (Nec-1) on $\mathrm{H}_{2} \mathrm{O}_{2}$-induced cathepsin D expression in UN-

of cathepsin $\mathrm{D}$ as well as expression of its double-chain form (43 and $33 \mathrm{kDa}$ ) did not differ between both cell phenotypes (Fig. 9). Moreover, the range of protection mediated by the cathepsin D inhibitor, pepstatin A, was similar to the effect of

Table 4 The effect of necrostatin-1 and pepstatin A alone and in combination against the hydrogen peroxide-induced cell damage in UN-SHSY5Y cells

\begin{tabular}{lcl}
\hline & $\begin{array}{l}\text { Cell viability } \\
\text { (\% control) }\end{array}$ & $\begin{array}{l}\text { LDH release } \\
(\% \text { control })\end{array}$ \\
\hline Control & $100.0 \pm 9.9$ & $100.2 \pm 6.4$ \\
$\mathrm{H}_{2} \mathrm{O}_{2}$ & $60.6 \pm 4.3^{* * *}$ & $358.3 \pm 17.2 * * *$ \\
$+\mathrm{Nec}-1$ & $90.3 \pm 4.1^{\# \#}$ & $277.2 \pm 14.1 * * *, \# \#$ \\
$+\mathrm{PsA}$ & $88.9 \pm 3.7^{\#}$ & $271.8 \pm 10.2 * * *, \# \#$ \\
$+\mathrm{PsA}+\mathrm{Nec}-1$ & $89.1 \pm 3.3^{\#}$ & $280.3 \pm 16.2 * * *, \# \#$ \\
\hline
\end{tabular}

UN-SH-SY5Y cells were pre-treated for 30 min with necrostatin-1 (Nec$1 ; 20 \mu \mathrm{M})$ and pepstatin $\mathrm{A}(\mathrm{PsA} ; 0.2 \mu \mathrm{M})$ alone and in combination followed by $24 \mathrm{~h}$ of treatment with $\mathrm{H}_{2} \mathrm{O}_{2}(0.25 \mathrm{mM})$

The MTT reduction and LDH release assays were employed for cell viability and toxicity assessments, respectively

Data were normalized to the vehicle-treated cells and are presented as the mean \pm SEM from 3 separate experiments with 5 repetitions each

$* * * P<0.001$ vs. vehicle-treated cells

${ }^{\#} P<0.05,{ }^{\# \#} P<0.01$, and ${ }^{\# \# \#} P<0.001$ vs. $\mathrm{H}_{2} \mathrm{O}_{2}$-treated cells d

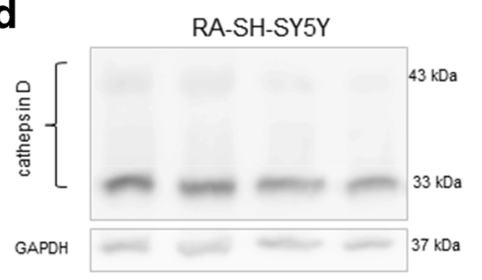

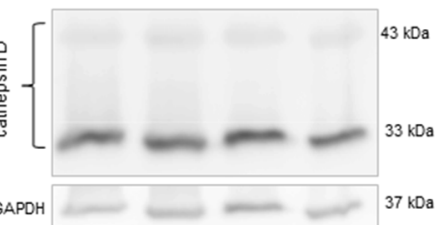
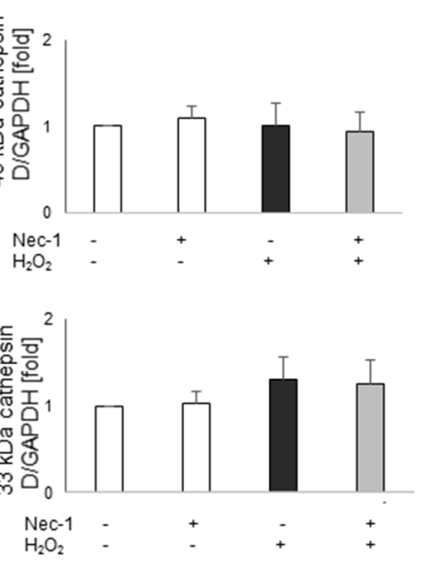

UN-SH-SY5Y
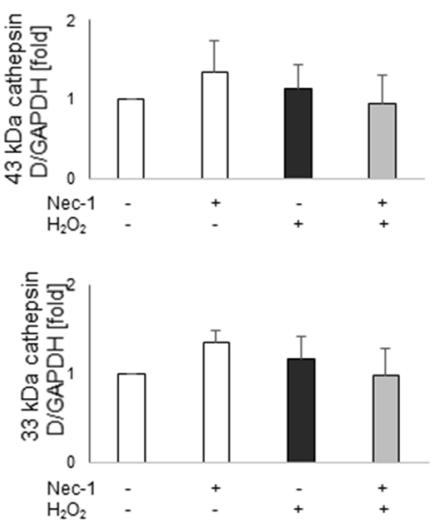

(c) and RA- (d) SH-SY5Y cells. The cells were pre-treated for $30 \mathrm{~min}$ with Nec-1 $(20 \mu \mathrm{M})$ followed by $18 \mathrm{~h}$ of treatment with $\mathrm{H}_{2} \mathrm{O}_{2}(0.25$ and $0.5 \mathrm{mM}$ for UN- and RA-SH-SY5Y cells, respectively). Expression of 43 and $33 \mathrm{kDa}$ forms of cathepsin $\mathrm{D}$ was done by Western blot method. Histograms show the quantified WB results from duplicate determinations in 2 independent experiments which were normalized to the protein loading control (GAPDH) and are expressed as fold of the control $\pm \mathrm{SEM}$

Nec-1 (Table 4) suggesting an interplay between necroptosis and lysosomal-permeability-induced cell death and a shared mechanism of action for both inhibitors. To our knowledge, there was only one report showing that necroptotic pathway was augmented by the activation of cathepsin D; however, that paper concerned activation of innate antiviral immune response in A549 cells (Wang et al. 2016). However, there are some reports linking Nec-1-mediated protection with its inhibitory effect on cathepsin B activity as has been shown in hippocampal neuronal programmed necrosis induced by ischemia/reperfusion injury (Yin et al. 2015) or in PC12 cells exposed to 6-OHDA (Wu et al. 2015). The activation of various forms of cathepsins seems to be specific for cell damaging factor and/or cell type since the activation of cathepsin D but not cathepsin B was observed in PC12 cells exposed to $\mathrm{H}_{2} \mathrm{O}_{2}$ (Lee et al. 2007) which was also confirmed in our previous study with SH-SY5Y cells (Chwastek et al. 2017). The active role of cathepsin D in oxidative stress-induced cell death in neuroblastoma cells was shown by siRNA-mediated downregulation of the enzyme, besides using PsA (Castino et al. 2008, 2010, 2011). One could doubt about cell permeability to PsA and efficient cathepsin D inhibition in lysosomes (Nicotra et al. 2010); however, this inhibitor has been used for many years by various research groups mostly in cellbased system (Chahory et al., 2010; Crabtree et al. 2014; Follo 
et al. 2007; Kanamori et al. 1998). Since cathepsin D has also physiological functions, maybe for neuroprotection strategies it will be more relevant to inhibit activity of this enzyme only when it is pathologically released from lysosomes. One could ask what mechanisms are responsible for induction of cathep$\sin \mathrm{D}$ activity by $\mathrm{H}_{2} \mathrm{O}_{2}$ and inhibitory effect of Nec-1 on this parameter. By WB analysis of two mature cathepsin D forms (43 and $33 \mathrm{kDa}$ ), we excluded the possibility of the impact of $\mathrm{H}_{2} \mathrm{O}_{2}$ and $\mathrm{Nec}-1$ on expression of this protein (Fig. 9c, d). It is likely that Nec-1 could chemically interact with the active site of cathepsin D in a similar way as PsA do; however, we did not find relevant reports. The only study regarding Nec-1 specificity tested its effect on the panel of 98 kinases and found that Nec-1 $<30 \mu \mathrm{M}$ inhibited only RIP1 (Biton and Ashkenazi 2011). It will be also interesting to study in the future whether curcumin engages cathepsin D inhibition in its protective action against oxidative stress.

Among other possible mechanisms which could be involved in Nec-1-mediated neuroprotection in SH-SY5Y cells, we excluded inhibition of caspase-3 (Table 2), calpains (Fig. 8a, b), or AIF translocation (Fig. 8c) although all of them were induced by $\mathrm{H}_{2} \mathrm{O}_{2}$. Some reported data pointed to a connection between AIF translocation and necroptosis induction (Bollino et al., 2015; Ji et al. 2011; Xu et al. 2010b, 2016) and that Nec1 inhibited the nuclear translocation of AIF in the model of Glu-evoked cell damage (Xu et al. 2007). Previously, we described a caspase-3-independent mechanism engaging AIF translocation in the model of $\mathrm{H}_{2} \mathrm{O}_{2}$-evoked cell damage in UN-SH-SY5Y cells (Jantas et al. 2015a). Although the present data confirmed AIF translocation in the oxidative stress model, it was not affected by Nec-1 treatment. It should be underlined that we observed the impact of curcumin on $\mathrm{H}_{2} \mathrm{O}_{2}$ induced caspase- 3 activation in UN-SH-SY5Y cells (data not shown) which could be a result of its ROS-scavenging activity (Szczepanowicz et al. 2016) and consequently inhibition of apoptotic processes. It should be mentioned that once translocated into the cytosol upon oxidative stress-induced permeabilization of the lysosomes $\left(\mathrm{H}_{2} \mathrm{O}_{2}\right.$ for $\left.30 \mathrm{~min}\right)$, cathep$\sin \mathrm{D}$ was shown to act on Bax to induce apoptosis in human neuroblastoma cells (Castino et al. 2007). However, this phenomenon is unlikely to be implicated in Nec-1 neuroprotective action against $\mathrm{H}_{2} \mathrm{O}_{2}$-evoked cell damage since under our experimental conditions cathepsin D was activated relatively late (after $18 \mathrm{~h}$, Chwastek et al. 2017) whereas apoptotic changes occurred earlier ( 9 and $18 \mathrm{~h}$ ) and were not changed by Nec-1 (Fig. 3b, c, Table 2). It is interesting that we found the influence of Nec-1 on $\mathrm{H}_{2} \mathrm{O}_{2}$-evoked neurite shortening (Fig. 3d) which confirms in vivo findings on participation of necroptosis in axonal degeneration and suggests a possible therapeutic intervention by its inhibition by Nec-1 (Arrázola et al. 2019). While this effect was observed in UN-SH-SY5Y at the late stage (18 h), in RA-SH-SY5Y cells, it was present at both studied time points ( 9 and 18 h) (Fig. 3d). The mechanisms by which Nec-1 interfere with $\mathrm{H}_{2} \mathrm{O}_{2}$-evoked reduction
Fig. 10 A schematic illustration of possible mechanisms by which the necrostatin-1 (Nec-1) mediates neuroprotection against the $\mathrm{H}_{2} \mathrm{O}_{2}$-induced cell damage in undifferentiated (UN-) and retinoic acid (RA)-differentiated SHSY5Y cells. Cathepsin D inhibition, but not caspase-3, calpain or AIF (apoptosis inducing factor) translocation inhibition, is proposed as a candidate mechanism associated with neuroprotection mediated by Nec-1 in oxidative stress $\left(\mathrm{H}_{2} \mathrm{O}_{2}\right)$ evoked cell damage. AcDEVD-Ac-DEVD-CHO, an inhibitor of caspase-3; MDLMDL28170, an inhibitor of calpains; CD - cathepsin D; PsA-pepstatin A, an inhibitor of cathepsin $\mathrm{D} ; \mathrm{H}_{2} \mathrm{O}_{2}$ - hydrogen peroxide; ROS - reactive oxygen species

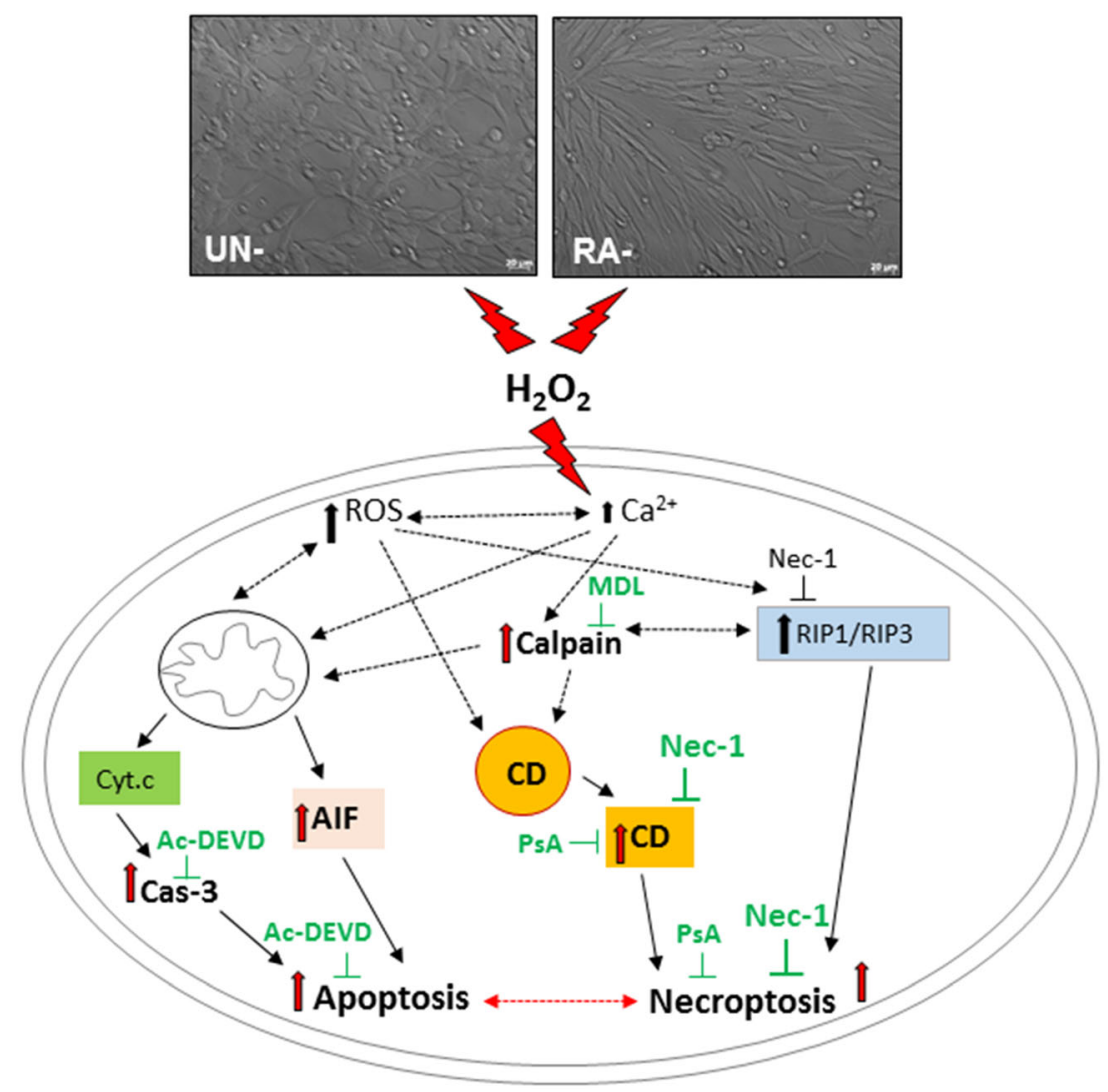


of neurites length are unknown yet and should be investigated in the future. It should be underlined that RA-differentiated cells are more suitable for monitoring of neurite outgrowth than undifferentiated ones (Lee et al. 2015; Miloso et al. 2004). Finally, we confirmed in RA-SH-SY5Y cells the $\mathrm{H}_{2} \mathrm{O}_{2}$ potency to induce ICE-like protease, caspase-1 activity (Jantas et al. 2018a) which was significantly attenuated only by Nec-1 + Curc combination (Table 3). Activation of this enzyme participates in another form of cell damage, namely pyroptosis (Espinosa-Oliva et al. 2019; Wang et al. 2019). Since previous data showed the activation of this proinflammatory protease in neuronal cell type, including SHSY5Y cells and neuroprotective potency of its inhibitors (Chen et al. 2019; Knaryan et al. 2014; Nath et al. 1996; Zhao et al. 2019a, b), it is highly probable that this mechanisms could be responsible for synergistic protective action of Nec-1 and curcumin against $\mathrm{H}_{2} \mathrm{O}_{2}$-evoked cell damage, observed in the present study.

Collectively, our data showed neuroprotective effects of the necroptosis inhibitor, Nec-1 against oxidative stress-induced cell damage, and pointed to involvement of cathepsin D inhibition in the mechanism of its action. Moreover, a cell typespecific interplay between necroptosis and apoptosis has been demonstrated (Fig. 10).

Acknowledgements We kindly thank Ms. Barbara Korzeniak for her excellent technical assistance.

Funding Information The study was supported by statutory funds of the Maj Institute of Pharmacology Polish Academy of Sciences.

\section{Compliance with Ethical Standards}

Conflict of Interest The authors declare that they have no conflicts of interest.

Open Access This article is licensed under a Creative Commons Attribution 4.0 International License, which permits use, sharing, adaptation, distribution and reproduction in any medium or format, as long as you give appropriate credit to the original author(s) and the source, provide a link to the Creative Commons licence, and indicate if changes were made. The images or other third party material in this article are included in the article's Creative Commons licence, unless indicated otherwise in a credit line to the material. If material is not included in the article's Creative Commons licence and your intended use is not permitted by statutory regulation or exceeds the permitted use, you will need to obtain permission directly from the copyright holder. To view a copy of this licence, visit http://creativecommons.org/licenses/by/4.0/.

\section{References}

Agholme L, Lindström T, Kågedal K, Marcusson J, Hallbeck M (2010) An in vitro model for neuroscience: differentiation of SH-SY5Y cells into cells with morphological and biochemical characteristics of mature neurons. J Alzheimers Dis 20:1069-1082
Arrázola MS, Saquel C, Catalán RJ, Barrientos SA, Hernandez DE, Martínez NW, Catenaccio A, Court FA (2019) Axonal degeneration is mediated by necroptosis activation. J Neurosci 39:3832-3844

Askalan R, Gabarin N, Armstrong EA, Fang Liu Y, Couchman D, Yager JY (2015) Mechanisms of neurodegeneration after severe hypoxicischemic injury in the neonatal rat brain. Brain Res 1629:94-103

Biton S, Ashkenazi A (2011) NEMO and RIP1 control cell fate in response to extensive DNA damage via TNF- $\alpha$ feedforward signaling. Cell 145:92-103

Bollino D, Balan I, Aurelian L (2015) Valproic acid induces neuronal cell death through a novel calpain-dependent necroptosis pathway. J Neurochem 133:174-186

Caccamo A, Branca C, Piras IS, Ferreira E, Huentelman MJ, Liang WS, Readhead B, Dudley JT, Spangenberg EE, Green KN, Belfiore R, Winslow W, Oddo S (2017) Necroptosis activation in Alzheimer's disease. Nat Neurosci 20:1236-1246

Castelli V, Benedetti E, Antonosante A, Catanesi M, Pitari G, Ippoliti R, Cimini A, d'Angelo M (2019) Neuronal cells rearrangement during aging and neurodegenerative disease: metabolism, oxidative stress and organelles dynamic. Front Mol Neurosci 12:132

Castino R, Bellio N, Nicotra G, Follo C, Trincheri NF, Isidoro C (2007) Cathepsin D-Bax death pathway in oxidative stressed neuroblastoma cells. Free Radic Biol Med 42:1305-1316

Castino R, Thepparit C, Bellio N, Murphy D, Isidoro C (2008) Akt induces apoptosis in neuroblastoma cells expressing a C98X vasopressin mutant following autophagy suppression. J Neuroendocrinol 20:1165-1175

Castino R, Bellio N, Follo C, Murphy D, Isidoro C (2010) Inhibition of PI3k class III-dependent autophagy prevents apoptosis and necrosis by oxidative stress in dopaminergic neuroblastoma cells. Toxicol Sci 117:152-162

Castino R, Fiorentino I, Cagnin M, Giovia A, Isidoro C (2011) Chelation of lysosomal iron protects dopaminergic SH-SY5Y neuroblastoma cells from hydrogen peroxide toxicity by precluding autophagy and Akt dephosphorylation. Toxicol Sci 123:523-541

Cenini G, Lloret A, Cascella R (2019) Oxidative stress in neurodegenerative diseases: from a mitochondrial point of view. Oxidative Med Cell Longev 2019:2105607

Chahory S, Keller N, Martin E, Omri B, Crisanti P, Torriglia A (2010) Light induced retinal degeneration activates a caspase-independent pathway involving cathepsin D. Neurochem Int 57:278-287

Chavez-Valdez R, Martin LJ, Flock DL, Northington FJ (2012) Necrostatin-1 attenuates mitochondrial dysfunction in neurons and astrocytes following neonatal hypoxia-ischemia. Neuroscience 219: 192-203

Chavez-Valdez R, Flock DL, Martin LJ, Northington FJ (2016) Endoplasmic reticulum pathology and stress response in neurons precede programmed necrosis after neonatal hypoxia-ischemia. Int J Dev Neurosci 48:58-70

Chen S, Zhou C, Yu H, Tao L, An Y, Zhang X, Wang Y, Wang Y, Xiao R (2019) 27-Hydroxycholesterol contributes to lysosomal membrane permeabilization-mediated pyroptosis in co-cultured SH-SY5Y cells and C6 cells. Front Mol Neurosci 12:14

Cheung YT, Lau WK, Yu MS, Lai CS, Yeung SC, So KF, Chang RC (2009) Effects of all-trans-retinoic acid on human SH-SY5Y neuroblastoma as in vitro model in neurotoxicity research. Neurotoxicology 30:127-135

Chinskey ND, Besirli CG, Zacks DN (2014) Retinal cell death and current strategies in retinal neuroprotection. Curr Opin Ophthalmol 25: 228-233

Chwastek J, Jantas D, Lasoń W (2017) The ATM kinase inhibitor KU55933 provides neuroprotection against hydrogen peroxide-induced cell damage via a $\gamma \mathrm{H} 2 \mathrm{AX} / \mathrm{p}$-p53/caspase-3-independent mechanism: inhibition of calpain and cathepsin D. Int J Biochem Cell Biol 87:38-53 
Cole KK, Perez-Polo JR (2002) Poly(ADP-ribose) polymerase inhibition prevents both apoptotic-like delayed neuronal death and necrosis after $\mathrm{H}(2) \mathrm{O}(2)$ injury. J Neurochem 82:19-29

Crabtree D, Dodson M, Ouyang X, Boyer-Guittaut M, Liang Q, Ballestas ME, Fineberg N, Zhang J (2014) Over-expression of an inactive mutant cathepsin D increases endogenous alpha-synuclein and cathepsin B activity in SH-SY5Y cells. J Neurochem 128:950-961

Dai MC, Zhong ZH, Sun YH, Sun QF, Wang YT, Yang GY, Bian LG (2013) Curcumin protects against iron induced neurotoxicity in primary cortical neurons by attenuating necroptosis. Neurosci Lett 536:41-46

Degterev A, Huang Z, Boyce M, Li Y, Jagtap P, Mizushima N, Cuny GD, Mitchison TJ, Moskowitz MA, Yuan J (2005) Chemical inhibitor of nonapoptotic cell death with therapeutic potential for ischemic brain injury. Nat Chem Biol 1:112-119

Degterev A, Hitomi J, Germscheid M, Ch'en IL, Korkina O, Teng X, Abbott D, Cuny GD, Yuan C, Wagner G, Hedrick SM, Gerber SA, Lugovskoy A, Yuan J (2008) Identification of RIP1 kinase as a specific cellular target of necrostatins. Nat Chem Biol 4:313-321

Degterev A, Maki JL, Yuan J (2013) Activity and specificity of necrostatin-1, small molecule inhibitor of RIP1 kinase. Cell Death Differ 20:366

Degterev A, Zhou W, Maki JL, Yuan J (2014) Assays for necroptosis and activity of RIP kinases. Methods Enzymol 545:1-33

Delehouzé C, Leverrier-Penna S, Le Cann F, Comte A, Jacquard-Fevai M, Delalande O, Desban N, Baratte B, Gallais I, Faurez F, Bonnet MC, Hauteville M, Goekjian PG, Thuillier R, Favreau F, Vandenabeele P, Hauet T, Dimanche-Boitrel MT, Bach S (2017) 6E11, a highly selective inhibitor of Receptor-Interacting Protein Kinase 1, protects cells against cold hypoxia-reoxygenation injury. Sci Rep 7:12931

Do YJ, Sul JW, Jang KH, Kang NS, Kim YH, Kim YG, Kim E (2017) A novel RIPK1 inhibitor that prevents retinal degeneration in a rat glaucoma model. Exp Cell Res 359:30-38

Dolga AM, Netter MF, Perocchi F, Doti N, Meissner L, Tobaben S, Grohm J, Zischka H, Plesnila N, Decher N, Culmsee C (2013) Mitochondrial small conductance SK2 channels prevent glutamate-induced oxytosis and mitochondrial dysfunction. J Biol Chem 288:10792-10804

Dong K, Zhu H, Song Z, Gong Y, Wang F, Wang W, Zheng Z, Yu Z, Gu Q, Xu X, Sun X (2012) Necrostatin-1 protects photoreceptors from cell death and improves functional outcome after experimental retinal detachment. Am J Pathol 181:1634-1641

Espinosa-Oliva AM, García-Revilla J, Alonso-Bellido IM, Burguillos MA (2019) Brainiac caspases: beyond the wall of apoptosis. Front Cell Neurosci 13:500

Follo C, Castino R, Nicotra G, Trincheri NF, Isidoro C (2007) Folding, activity and targeting of mutated human cathepsin $\mathrm{D}$ that cannot be processed into the double-chain form. Int J Biochem Cell Biol 39: 638-649

Fraczek-Szczypta A, Jantas D, Ciepiela F, Grzonka J, Bernasik A, Marzec M (2018) Carbon nanomaterials coatings - properties and influence on nerve cells response. Diam Relat Mater 84:127-140

Funakoshi T, Aki T, Tajiri M, Unuma K, Uemura K (2016) Necroptosislike neuronal cell death caused by cellular cholesterol accumulation. J Biol Chem 291:25050-25065

Ito K, Eguchi Y, Imagawa Y, Akai S, Mochizuki H, Tsujimoto Y (2017) MPP+ induces necrostatin-1- and ferrostatin-1-sensitive necrotic death of neuronal SH-SY5Y cells. Cell Death Discov 3:17013

Jantas D, Krawczyk S, Lason W (2014a) The predominant protective effect of tianeptine over other antidepressants in models of neuronal apoptosis: the effect blocked by inhibitors of MAPK/ERK1/2 and PI3-K/Akt pathways. Neurotox Res 25:208-225

Jantas D, Greda A, Golda S, Korostynski M, Grygier B, Roman A, Pilc A, Lason W (2014b) Neuroprotective effects of metabotropic glutamate receptor group II and III activators against MPP(+)-induced cell death in human neuroblastoma SH-SY5Y cells: the impact of cell differentiation state. Neuropharmacology 83:36-53

Jantas D, Piotrowski M, Lason W (2015a) An involvement of PI3-K/Akt activation and inhibition of AIF translocation in neuroprotective effects of undecylenic acid (UDA) against pro-apoptotic factors-induced cell death in human neuroblastoma SH-SY5Y cells. J Cell Biochem 116:2882-2895

Jantas D, Greda A, Leskiewicz M, Grygier B, Pilc A, Lason W (2015b) Neuroprotective effects of mGluR II and III activators against staurosporine- and doxorubicin-induced cellular injury in $\mathrm{SH}-$ SY5Y cells: new evidence for a mechanism involving inhibition of AIF translocation. Neurochem Int 88:124-137

Jantas D, Grygier B, Gołda S, Chwastek J, Zatorska J, Tertil M (2018a) An endogenous and ectopic expression of metabotropic glutamate receptor 8 (mGluR8) inhibits proliferation and increases chemosensitivity of human neuroblastoma and glioma cells. Cancer Lett 432:1-16

Jantas D, Grygier B, Zatorska J, Lasoń W (2018b) Allosteric and orthosteric activators of mglur8 differentially affect the chemotherapeutic-induced human neuroblastoma SH-SY5Y cell damage: the impact of cell differentiation state. Basic Clin Pharmacol Toxicol 123:443-451

Ji D, Kamalden TA, del Olmo-Aguado S, Osborne NN (2011) Light- and sodium azide-induced death of RGC- 5 cells in culture occurs via different mechanisms. Apoptosis 16:425-437

Kanamori S, Waguri S, Shibata M, Isahara K, Ohsawa Y, Konishi A, Kametaka S, Watanabe T, Ebisu S, Kominami E, Uchiyama Y (1998) Overexpression of cation-dependent mannose 6-phosphate receptor prevents cell death induced by serum deprivation in $\mathrm{PC} 12$ cells. Biochem Biophys Res Commun 251:204-208

Kim S, Dayani L, Rosenberg PA, Li J (2010) RIP1 kinase mediates arachidonic acid-induced oxidative death of oligodendrocyte precursors. Int J Physiol Pathophysiol Pharmacol 2:137-147

Knaryan VH, Samantaray S, Park S, Azuma M, Inoue J, Banik NL (2014) SNJ-1945, a calpain inhibitor, protects SH-SY5Y cells against MPP(+) and rotenone. J Neurochem 130:280-290

Koshinuma S, Miyamae M, Kaneda K, Kotani J, Figueredo VM (2014) Combination of necroptosis and apoptosis inhibition enhances cardioprotection against myocardial ischemia-reperfusion injury. J Anesth 28:235-241

Lee DC, Mason CW, Goodman CB, Holder MS, Kirksey OW, Womble TA, Severs WB, Palm DE (2007) Hydrogen peroxide induces lysosomal protease alterations in PC12 cells. Neurochem Res 32:14991510

Lee HO, Byun YJ, Cho KO, Kim SY, Lee SB, Kim HS, Kwon OJ, Jeong SW (2011) GS28 protects neuronal cell death induced by hydrogen peroxide under glutathione-depleted condition. Korean J Physiol Pharmacol 15:149-156

Lee JS, Lipatov A, Ha L, Shekhirev M, Andalib MN, Sinitskii A, Lim JY (2015) Graphene substrate for inducing neurite outgrowth. Biochem Biophys Res Commun 460:267-273

Li N, He Y, Wang L, Mo C, Zhang J, Zhang W, Li J, Liao Z, Tang X, Xiao $\mathrm{H}$ (2011) D-galactose induces necroptotic cell death in neuroblastoma cell lines. J Cell Biochem 112:3834-3844

Li W, Liu J, Chen JR, Zhu YM, Gao X, Ni Y, Lin B, Li H, Qiao SG, Wang C, Zhang HL, Ao GZ (2018) Neuroprotective effects of DTIO, a novel analogue of Nec-1, in acute and chronic stages after ischemic stroke. 390:12-29

Liu Q, Qiu J, Liang M, Golinski J, van Leyen K, Jung JE, You Z, Lo EH, Degterev A, Whalen MJ (2014) Akt and mTOR mediate programmed necrosis in neurons. Cell Death Dis 5:e1084

Lopes FM, Schroder R, da Frota ML Jr, Zanotto-Filho A, Muller CB, Pires AS, Meurer RT, Colpo GD, Gelain DP, Kapczinski F, Moreira JC, Fernandes MC, Klamt F (2010) Comparison between proliferative and neuron-like SH-SY5Y cells as an in vitro model for Parkinson disease studies. Brain Res 1337:85-94 
Mhillaj E, Tarozzi A, Pruccoli L, Cuomo V, Trabace L, Mancuso C (2019) Curcumin and heme oxygenase: neuroprotection and beyond. Int J Mol Sci 20:E2419

Miloso M, Villa D, Crimi M, Galbiati S, Donzelli E, Nicolini G, Tredici G (2004) Retinoic acid-induced neuritogenesis of human neuroblastoma SH-SY5Y cells is ERK independent and PKC dependent. J Neurosci Res 75:241-252

Nath R, Raser KJ, McGinnis K, Nadimpalli R, Stafford D, Wang KK (1996) Effects of ICE-like protease and calpain inhibitors on neuronal apoptosis. Neuroreport 8:249-255

Ni Y, Gu WW, Liu ZH, Zhu YM, Rong JG, Kent TA, Li M, Qiao SG, An JZ, Zhang HL (2018) RIP1K contributes to neuronal and astrocytic cell death in ischemic stroke via activating autophagic-lysosomal pathway. 371:60-74

Nicotra G, Castino R, Follo C, Peracchio C, Valente G, Isidoro C (2010) The dilemma: does tissue expression of cathepsin $\mathrm{D}$ reflect tumor malignancy? The question: does the assay truly mirror cathepsin $\mathrm{D}$ mis-function in the tumor? Cancer Biomark 7:47-64

No H, Bang Y, Lim J, Kim SS, Choi HS, Choi HJ (2010) Involvement of induction and mitochondrial targeting of orphan nuclear receptor Nur77 in 6-OHDA-induced SH-SY5Y cell death. Neurochem Int $56: 620-626$

Northington FJ, Chavez-Valdez R, Graham EM, Razdan S, Gauda EB, Martin LJ (2011) Necrostatin decreases oxidative damage, inflammation, and injury after neonatal HI. J Cereb Blood Flow Metab 31: 178-189

Park SY, Kim DY, Kang JK, Park G, Choi YW (2014) Involvement of activation of the Nrf2/ARE pathway in protection against 6-OHDAinduced SH-SY5Y cell death by $\alpha$-iso-cubebenol. Neurotoxicology 44:160-168

Park JH, Kim CK, Lee SB, Lee KH, Cho SW, Ahn JY (2016) Akt attenuates apoptotic death through phosphorylation of $\mathrm{H} 2 \mathrm{~A}$ under hydrogen peroxide-induced oxidative stress in PC12 cells and hippocampal neurons. Sci Rep 6:21857

Polito L, Bortolotti M, Pedrazzi M, Mercatelli D, Battelli MG, Bolognesi A (2016) Apoptosis and necroptosis induced by stenodactylin in neuroblastoma cells can be completely prevented through caspase inhibition plus catalase or necrostatin-1. Phytomedicine 23:32-41

Qinli Z, Meiqing L, Xia J, Li X, Weili G, Xiuliang J, Junwei J, Hailan Y, Ce Z, Qiao N (2013) Necrostatin-1 inhibits the degeneration of neural cells induced by aluminum exposure. Restor Neurol Neurosci 31:543-555

Re DB, Le Verche V, Yu C, Amoroso MW, Politi KA, Phani S, Ikiz B, Hoffmann L, Koolen M, Nagata T, Papadimitriou D, Nagy P, Mitsumoto H, Kariya S, Wichterle H, Henderson CE, Przedborski S (2014) Necroptosis drives motor neuron death in models of both sporadic and familial ALS. Neuron 81:1001-1008

Rosenbaum DM, Degterev A, David J, Rosenbaum PS, Roth S, Grotta JC, Cuny GD, Yuan J, Savitz SI (2010) Necroptosis, a novel form of caspase-independent cell death, contributes to neuronal damage in a retinal ischemia-reperfusion injury model. J Neurosci Res 88:1569-1576

Sang Q, Sun D, Chen Z, Zhao W (2018) NGF and PI3K/Akt signaling participate in the ventral motor neuronal protection of curcumin in sciatic nerve injury rat models. Biomed Pharmacother 103:1146-1153

Szczepanowicz K, Jantas D, Piotrowski M, Staroń J, Leśkiewicz M, Regulska M, Lasoń W, Warszyński P (2016) Encapsulation of curcumin in polyelectrolyte nanocapsules and their neuroprotective activity. Nanotechnology 27:355101

Tieu K, Zuo DM, Yu PH (1999) Differential effects of staurosporine and retinoic acid on the vulnerability of the SH-SY5Y neuroblastoma cells: involvement of bcl-2 and p53 proteins. J Neurosci Res 58:426-435

Uğuz AC, Öz A, Nazıroğlu M (2016) Curcumin inhibits apoptosis by regulating intracellular calcium release, reactive oxygen species and mitochondrial depolarization levels in SH-SY5Y neuronal cells. J Recept Signal Transduct Res 36:395-401

Vieira M, Fernandes J, Carreto L, Anuncibay-Soto B, Santos M, Han J, Fernández-López A, Duarte CB, Carvalho AL, Santos AE (2014) Ischemic insults induce necroptotic cell death in hippocampal neurons through the up-regulation of endogenous RIP3. Neurobiol Dis 68:26-36

Wang Y, Wang H, Tao Y, Zhang S, Wang J, Feng X (2014) Necroptosis inhibitor necrostatin-1 promotes cell protection and physiological function in traumatic spinal cord injury. Neuroscience 266:91-101

Wang W, Wang WH, Azadzoi KM, Su N, Dai P, Sun J, Wang Q, Liang P, Zhang W, Lei X, Yan Z, Yang JH (2016) Activation of innate antiviral immune response via double-stranded RNA-dependent RLR receptor-mediated necroptosis. Sci Rep 6:22550

Wang J, Liu Y, Li XH, Zeng XC, Li J, Zhou J, Xiao B, Hu K (2017) Curcumin protects neuronal cells against status-epilepticus-induced hippocampal damage through induction of autophagy and inhibition of necroptosis. Can J Physiol Pharmacol 95:501-509

Wang S, Yuan YH, Chen NH, Wang HB (2019) The mechanisms of NLRP3 inflammasome/pyroptosis activation and their role in Parkinson's disease. Int Immunopharmacol 67:458-464

Wenker SD, Chamorro ME, Vota DM, Callero MA, Vittori DC, Nesse AB (2010) Differential antiapoptotic effect of erythropoietin on undifferentiated and retinoic acid-differentiated SH-SY5Y cells. J Cell Biochem 110:151-161

Wu JR, Wang J, Zhou SK, Yang L, Yin JL, Cao JP, Cheng YB (2015) Necrostatin-1 protection of dopaminergic neurons. Neural Regen Res 10:1120-1124

Xie T, Peng W, Yan C, Wu J, Gong X, Shi Y (2013) Structural insights into RIP3-mediated necroptotic signaling. Cell Rep 5:70-78

Xiong K, Liao H, Long L, Ding Y, Huang J, Yan J (2016) Necroptosis contributes to methamphetamine-induced cytotoxicity in rat cortical neurons. Toxicol in Vitro 35:163-168

$\mathrm{Xu}$ X, Chua CC, Kong J, Kostrzewa RM, Kumaraguru U, Hamdy RC, Chua BH (2007) Necrostatin-1 protects against glutamate-induced glutathione depletion and caspase-independent cell death in HT-22 cells. J Neurochem 103(5):2004-2014

Xu X, Chua KW, Chua CC, Liu CF, Hamdy RC, Chua BH (2010a) Synergistic protective effects of humanin and necrostatin-1 on hypoxia and ischemia/reperfusion injury. Brain Res 1355:189-194

Xu X, Chua CC, Zhang M, Geng D, Liu CF, Hamdy RC, Chua BH (2010b) The role of PARP activation in glutamate-induced necroptosis in HT-22 cells. Brain Res 1343:206-212

Xu Y, Wang J, Song X, Qu L, Wei R, He F, Wang K, Luo B (2016) RIP3 induces ischemic neuronal DNA degradation and programmed necrosis in rat via AIF. Sci Rep 6:29362

Xu L, Ding L, Su Y, Shao R, Liu J, Huang Y (2019) Neuroprotective effects of curcumin against rats with focal cerebral ischemiareperfusion injury. Int J Mol Med 43:1879-1887

Yamanaka K, Saito Y, Yamamori T, Urano Y, Noguchi N (2011) 24(S)hydroxycholesterol induces neuronal cell death through necroptosis, a form of programmed necrosis. J Biol Chem 286:24666-24673

Yang R, Hu K, Chen J, Zhu S, Li L, Lu H, Li P, Dong R (2017a) Necrostatin-1 protects hippocampal neurons against ischemia/ reperfusion injury via the RIP3/DAXX signaling pathway in rats. Neurosci Lett 651:207-215

Yang SH, Lee DK, Shin J, Lee S, Baek S, Kim J, Jung H, Hah JM, Kim Y (2017b) Nec-1 alleviates cognitive impairment with reduction of $A \beta$ and tau abnormalities in APP/PS1 mice. EMBO Mol Med 9:61-77

Yang SH, Shin J, Shin NN, Hwang JH, Hong SC, Park K, Lee JW, Lee S, Baek S, Kim K, Cho I, Kim Y (2019) A small molecule Nec-1 directly induces amyloid clearance in the brains of aged APP/PS1 mice. Sci Rep 9:4183

Yin B, Xu Y, Wei RL, He F, Luo BY, Wang JY (2015) Inhibition of receptor-interacting protein 3 upregulation and nuclear translocation involved in necrostatin-1 protection against hippocampal neuronal 
programmed necrosis induced by ischemia/reperfusion injury. Brain Res 1609:63-71

Zhan L, Lu Z, Zhu X, Xu W, Li L, Li X, Chen S, Sun W, Xu E (2019) Hypoxic preconditioning attenuates necroptotic neuronal death induced by global cerebral ischemia via Drp1-dependent signaling pathway mediated by CaMKII $\alpha$ inactivation in adult rats. FASEB J 33:1313-1329

Zhang QL, Niu Q, Ji XL, Conti P, Boscolo P (2008) Is necroptosis a death pathway in aluminum-induced neuroblastoma cell demise? Int $\mathrm{J}$ Immunopathol Pharmacol 21:787-796

Zhang M, Li J, Geng R, Ge W, Zhou Y, Zhang C, Cheng Y, Geng D (2013) The inhibition of ERK activation mediates the protection of necrostatin-1 on glutamate toxicity in HT-22 cells. Neurotox Res 24:64-70

Zhang S, Wang Y, Li D, Wu J, Si W, Wu Y (2016) Necrostatin-1 attenuates inflammatory response and improves cognitive function in chronic ischemic stroke mice. Medicines (Basel) 3:E16
Zhao H, Jaffer T, Eguchi S, Wang Z, Linkermann A, Ma D (2015) Role of necroptosis in the pathogenesis of solid organ injury. Cell Death Dis 6:e1975

Zhao MW, Yang P, Zhao LL (2019a) Chlorpyrifos activates cell pyroptosis and increases susceptibility on oxidative stress-induced toxicity by miR-181/SIRT1/PGC-1 $\alpha / \mathrm{Nrf} 2$ signaling pathway in human neuroblastoma SH-SY5Y cells: Implication for association between chlorpyrifos and Parkinson's disease. Environ Toxicol 34: 699-707

Zhao N, Sun C, Zheng M, Liu S, Shi R (2019b) Amentoflavone suppresses amyloid $\beta 1-42$ neurotoxicity in Alzheimer's disease through the inhibition of pyroptosis. Life Sci 239:117043

Publisher's Note Springer Nature remains neutral with regard to jurisdictional claims in published maps and institutional affiliations. 